University of Florida Levin College of Law

UF Law Scholarship Repository

\title{
Beach Law Cleanup: How Sea-Level Rise Has Eroded the Ambulatory Boundaries Legal Framework
}

Alyson C. Flournoy

University of Florida Levin College of Law, flournoy@law.ufl.edu

Follow this and additional works at: https://scholarship.law.ufledu/facultypub

Part of the Environmental Law Commons, and the Property Law and Real Estate Commons

\section{Recommended Citation}

Alyson C. Flournoy, Beach Law Cleanup: How Sea-Level Rise Has Eroded the Ambulatory Boundaries Legal Framework, 42 Vermont L. Rev. 89 (2017), available at 


\title{
BEACH LAW CLEANUP: HOW SEA-LEVEL RISE HAS ERODED THE AMBULATORY BOUNDARIES LEGAL FRAMEWORK
}

\author{
Alyson C. Flournoy* \\ INTRODUCTION \\ 90 \\ I. BEACH LAW: WHERE SOVEREIGNTY LANDS MEET LITTORAL

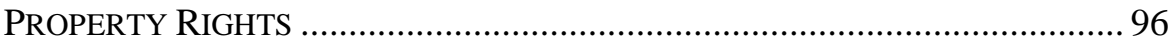 \\ A. Sovereign Submerged Lands and the Public Trust............................ 98 \\ B. Private Lands and Littoral Rights .................................................. 100 \\ C. The Dynamic Boundary and Its Legal Significance ......................... 101 \\ D. The Rationales Supporting the Doctrines of Accretion/Erosion

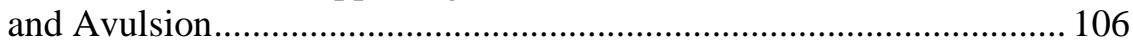

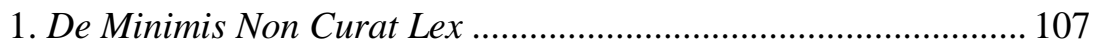

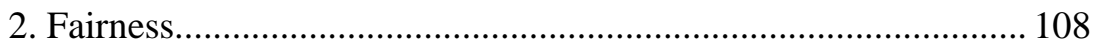 \\ 3. Protection of the Sovereign/Public Interest................................. 109 \\ 4. Social Utility ................................................................................ 110 \\ 5. Protection of Littoral Landowners' Right of Access to Water..... 111 \\ II. ERODING FOUNDATIONS: HOW SEA-LEVEL RISE UNDERMINES THE \\ AMBULATORY BOUNDARIES FRAMEWORK …….................................... 111 \\ A. Four Archaic Factual Assumptions ............................................... 113 \\ 1. Predictability ........................................................................... 113 \\ a. The Assumption: Changes in Water Bodies Are Unpredictable .. 113 \\ b. The Reality: Sea-level Rise Is Neither Random nor Totally

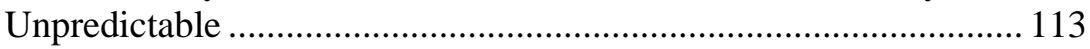

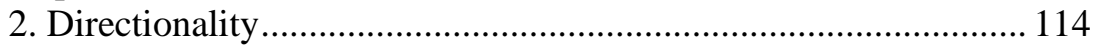 \\ a. The Assumption: Changes in Water Bodies Are Equally \\ Likely to Move the Boundary in Either Direction.............................. 114 \\ b. The Reality: Sea-level Rise is Unidirectional .............................. 115 \\ 3. Frequency and Scope of Change .............................................. 117 \\ a. The Assumption: Changes in Water Bodies Are Episodic, \\ Occasional, and of Limited Geographic Scope ................................ 117 \\ b. The Reality: Sea-level Rise Is Ongoing and Geographically \\ Pervasive

* Alumni Research Scholar and Professor of Law, University of Florida Levin College of Law. The thinking behind this article benefited greatly from comments of numerous colleagues at an incubator workshop at UF Law and from thoughtful comments from attendees at the 19th Annual Conference on Litigating Takings, where it was presented. I am grateful to Rainey Booth, Justin Caron, Alex Menendez, and Danielle Rapapport for their able research assistance; to Christine Klein, Peter Byrne, and John Echeverria for their very helpful comments on an early draft; and to Richard Hamann and Tom Ankersen for generously sharing their expertise on Florida ambulatory boundaries law and related topics. 
4. Homogeneity of Water Bodies

a. The Assumption: Changes in Oceans, Lakes, Rivers, and

Streams All Share the Same Characteristics

b. The Reality: Sea-level Rise Is a Distinctively Coastal Process.... 120

B. How Archaic Factual Assumptions Undermine the Rationales for the Ambulatory Boundaries Framework.

1. De Minimis Non Curat Lex and Archaic Assumptions About

Predictability, Frequency, and Scope of Change.

2. Fairness and Archaic Assumptions About Predictability, Directionality, Frequency, Scope of Change, and Homogeneity of Waterfront Contexts.

3. Protection of the Sovereign/Public Interest and Archaic

Assumptions About Predictability, Directionality, Frequency, and Scope of Change

4. Productive Use of Land/Social Utility and Archaic Assumptions

About Directionality, Frequency, and Scope of Change... 128

5. Access to Water and Archaic Assumptions About

Directionality of Change 130

III. CLEARING AWAY THE DEBRIS: DETERMINING THE APPLICABLE

LAW IN A POST-AMBULATORY BOUNDARIES LEGAL LANDSCAPE............ 131

A. The Relevance of Changed Facts: What's a Court to Do? ............... 132

B. Option One: Apply the Ambulatory Boundaries Framework with

Explicit Consideration of the Changed Factual Context ....................... 136

C. Option Two: Set Aside the Ambulatory Boundaries Framework.... 137

D. Objections to the Proposal to Set Aside the Ambulatory

Boundaries Framework in the Context of Sea-level Rise. 146

CONCLUSION

152

\section{INTRODUCTION}

As the sea level rises, the boundaries between privately owned coastal property and sovereign submerged lands held in public trust are becoming increasingly contested. ${ }^{1}$ The common law doctrines that determine these

1. See generally Walton County v. Stop the Beach Renourishment, Inc., 998 So. 2d 1102, 1106 (Fla. 2008) (involving a boundary dispute between private property owners and Walton County arising out of efforts to re-nourish beaches critically eroded by a hurricane); Stop the Beach Renourishment, Inc. v. Fla. Dep’t of Envtl. Prot., 560 U.S. 702, 703 (2010) (affirming the Florida Supreme Court's decision); see also Deborah Wheeler, Beach Access Debate Continues to Be a Hot Topic, Walton Sun (Mar. 23, 2016, 1:00 PM) [hereinafter Beach Access], http://www.waltonsun.com/article/20160323/NEWS/160329713 (chronicling citizens' concerns over their rights to use the beach); Deborah Wheeler, Attorney Retained in Walton Beach Access Controversy, Nw. Fla. DAILY NEWs (Apr. 13, 2016, 11:09 AM) [hereinafter Attorney Retained], http://www.nwfdailynews.com/news/20160413/attorney-retained-in-walton-beach-access- 
boundaries under conditions of change-primarily accretion, erosion, reliction, and avulsion-have important implications for all those involved in adaptation planning along our coasts. ${ }^{2}$ This includes private owners of coastal property, local government officials seeking to develop and implement adaptation strategies, beachgoers seeking to use shrinking beaches, beach-tourism-dependent businesses, and courts facing cases involving boundary disputes at the water's moving edge. ${ }^{3}$ This paper raises the questions of whether and how the common law doctrines remain relevant and applicable in an era of sea-level rise.

These doctrines create a legal framework that is problematic even without sea-level rise. Commentators justly criticize these doctrines for being vague, ${ }^{4}$ lacking a coherent justification, ${ }^{5}$ being inefficient, ${ }^{6}$ and

controversy (stating that conflict over boundaries often arises in the context of disputes over public rights to use the dry sand beach). Litigation over these rights is also becoming increasingly common. See, e.g., Trepanier v. County of Volusia, 965 So. 2d 276, 278 (Fla. Dist. Ct. App. 2007) (discussing a dispute between littoral landowner and county over public use after erosion reduced a dry-sand beach area); Reynolds v. County of Volusia, 659 So. 2d 1186, 1187 (Fla. Dist. Ct. App. 1995) (discussing a dispute over county right to regulate beach); Lizette Alvarez, Florida Beachgoers Cling to a Right to Make the Sand Their Driveway, N.Y. Times (Jan. 26, 2016), https://www.nytimes.com/2016/01/27/us/ florida-beachgoers-cling-to-a-right-to-make-the-sand-their-driveway.html (chronicling legal battles in Florida over public access to beaches).

2. See generally Phillip Wm. Lear, Accretion, Reliction, Erosion, and Avulsion: A Survey of Riparian and Littoral Title Problem, 11 J. ENERGy NAT. RES. \& ENVTL L. 265, 275-82 (1991) (explaining in depth the doctrines associated with the movement of water and their subsequent effects on shoreline titles).

3. See Holly Doremus, Climate Change and the Evolution of Property Rights, 1 U.C. IRVINE L. REV. 1091, 1106 (2011) (discussing rising litigation between private coastal owners and the government); Donna R. Christie, Of Beaches, Boundaries and SOBs, 25 J. LAND USE \& ENVTL. L. 19, 38 (2009) (discussing financial dynamics of coastal property and beaches for the government).

4. Joseph L. Sax, The Accretion/Avulsion Puzzle: Its Past Revealed, Its Future Proposed, 23 Tul. EnVTL. L.J. 305, 351 (2010) [hereinafter Sax, Accretion]; David Rusk, Fix It or Forget It: How the Doctrine of Avulsion Threatens the Efficacy of Rolling Easements, 51 Houston L. REv. 297, 323-24 (2013); Richard J. McLaughlin, Rolling Easements as a Response to Sea Level Rise in Coastal Texas: Current Status of the Law After Severance v. Patterson, 26 J. LAND USE \& ENVTL. L. 365, 391 (2011); see also Severance v. Patterson, 370 S.W.3d 705, 734 (Tex. 2012) (Medina, J., dissenting) (“[T]he Court's vague distinction between gradual and sudden or slight and dramatic changes to the coastline jeopardizes the public's right to free and open beaches ....”).

5. Sax, Accretion, supra note 4, at 351; Rusk, supra note 4, at 325-26; see also Joseph L. Sax, Some Unorthodox Thoughts About Rising Sea Levels, Beach Erosion, and Property Rights, 11 VT. J. ENVTL. L. 641, 645 (2010) [hereinafter Sax, Rising Sea Levels] (explaining how the doctrine could be interpreted as unreasonable).

6. Sax, Accretion, supra note 4, at 351; Christie, supra note 3, at 54 (alluding to the factors that result in inefficient methods); see also McLaughlin, supra note 4, at 392 (explaining that property owners' efforts to rebuild will lead to inefficient public response to disaster and expensive litigation); 9 Richard R. Powell, Powell on Real Property § 66.02[1] nn.1-2, 4 (Michael Allan Wolf ed., 2016) (discussing the challenge of proving the factual prerequisites). 
tending to create uncertainty. ${ }^{7}$ They have pointed out that the primary distinction the doctrines draw-between changes that are slow and imperceptible and those that are rapid and observable-creates heavy evidentiary demands with little benefit, and is ill matched to a reality where many changes reflect a combination of rapid and slow processes. ${ }^{8}$ Further, commentators have suggested that the doctrines do not serve social values well, particularly in an era of sea-level rise. ${ }^{9}$ These critiques and the reforms proposed by the commentators are valuable contributions; over time, courts may take note of these concerns. However, real property law is a field well known for its archaism and the slow pace at which courts typically adopt change. ${ }^{10}$ The courts' conservatism about property law is amplified by their concern about upsetting landowners' expectations without notice or fair process, which the specter of a judicial takings theory heightens. ${ }^{11}$

This paper approaches these doctrines from a different perspective: a perspective focused specifically on their application in an era of sea-level rise. It asks whether, on their own terms, these doctrines apply to cases involving coastal property in an era of documented and ongoing sea-level rise. Building on the insights of other legal scholars who have explored and challenged traditional thinking about these doctrines, this paper asks whether sea-level rise so changes material, doctrinally relevant facts that cases arising along our coasts today are distinguishable from cases in prior eras. ${ }^{12}$ The doctrines of accretion, erosion, reliction, and avulsion developed

7. See Christie, supra note 3, at 54 (highlighting the reasons for uncertainty in the existing legal framework); see also Severance, 370 S.W.3d at 735 (Medina, J., dissenting) ("But the exact metes and bounds of the beachfront property line cannot be ascertained with any specificity at any given time other than by reference to the mean high tide.”); Rusk, supra note 4, at 323.

8. Sax, Rising Sea Levels, supra note 5, at 645; McLaughlin, supra note 4, at 382-83; Rusk, supra note 4, at 326-27.

9. Sax, Rising Sea Levels, supra note 5, at 645; Rusk, supra note 4 at 325 (suggesting that application of the doctrine of avulsion jeopardizes public access to beaches); Sax, Accretion, supra note 4, at 356; Christie, supra note 3, at 48-52 (critiquing the Florida Supreme Court for misapplying the ambulatory boundaries framework in Walton County v. Stop the Beach Renourishment, Inc.).

10. A primary justification for this is the theory that a primary goal of property law is to promote stability. See John A. Lovett, Property and Radically Changed Circumstances, 74 TENN. L. REV. 463, 466 (2007) (surveying theories of property as a tool to promote stability).

11. See Stop the Beach Renourishment, Inc. v. Fla. Dep't of Envtl. Prot., 560 U.S 702, 713-14 (2010) (plurality opinion supporting application of the Takings Clause to judicial decisions).

12. See Lovett, supra note 10 , at 469,470 (providing a detailed exploration of the relative capacity of different property relationships to respond to radically changed circumstances). Lovett defines radically changed circumstances to include events that are sudden, unexpected, intensely disruptive, and geographically pervasive. Id. at 470-73. As Part II makes clear, the changes this paper focuses on may not qualify as either sudden or unexpected. Using Hurricane Katrina as a case study, Lovett proposes normative criteria for evaluating the resilience of property relationships, including landlord-tenant and mortgagor-mortgagee. Id. at 495, 496, 515. The normative criteria he proposes for 
from and were applied in cases from prior eras. It argues that the factual differences between the historic context and the conditions along our coasts today demand that courts take account of these changes as they apply the law governing coastal boundaries. ${ }^{13}$

After laying out the contours of the relevant common law doctrines and the rationales offered to support their application, the article identifies four factual assumptions underlying the application of these doctrines. It goes on to show that these assumptions are no longer true. These doctrines have always dealt with dynamic water bodies, but sea-level rise changes the dynamic coastal environment in four materially important ways. ${ }^{14}$ This article describes how the facts that characterize the context of sea-level rise differ from those at all prior times in modern history. It then examines how these factual differences affect whether and how each of the five principal rationales underlying these common law doctrines remain applicable. It concludes that the foundations for applying the ambulatory boundaries framework have been so undermined in the context of sea-level rise that courts should reconsider the application of this body of law to cases involving coastal erosion. It then offers two approaches that courts might use to adapt the law to the new realities.

evaluating resilience include whether, under conditions of radical change, the regimes: (1) encourage parties to spread risk and to enlist outside resources; (2) offer economies of scale; (3) facilitate exit for those needing or wishing to exit in ways that promote trust and cooperation; (4) facilitate entrance for others; and (5) spread access to common resources more widely and equitably. Id. at 496 . One could analyze the rule governing the relationship between coastal landowners and the sovereign using these criteria.

13. This project bears some relationship to the growing literature exploring whether and how statutory law should adapt to deal with a changing climate. See, e.g., J.B. Ruhl, Climate Change Adaptation and the Structural Transformation of Environmental Law, 40 ENVTL. L. 363, 392-96 (2010) [hereinafter Ruhl, Climate Change Adaptation] (explaining how environmental sciences have evolved in response to climate change and how environmental law must now do the same); J.B. Ruhl, Climate Change and the Endangered Species Act: Building Bridges to the No-Analog Future, 88 B.U. L. REV. 1374, 1374 (2008) [hereinafter Ruhl, Structural Transformation] (arguing that resilience and adaptive capacity are the keys to a legal system well adapted to intense and long-term demands brought about by climate change); Holly Doremus, Adapting to Climate Change with Law that Bends Without Breaking, 2 SAN Diego J. Climate \& ENERGy L. 45, 46-48 (2010) (suggesting that less rigid environmental laws may lead to greater advances in climate change adaptation); Victor B. Flatt, Adapting Laws for a Changing World: A Systemic Approach to Climate Change Adaptation, 64 FLA. L. REV. 269, 273-74 (2012) (outlining policy responses to advance climate change adaptation solutions). The significant difference is that this article focuses on common law doctrines rather than statutory law. As Professor Ruhl points out in an article focused on making the legal system itself adaptive, the common law possesses a unique evolutionary capacity. J.B. Ruhl, General Design Principles for Resilience and Adaptive Capacity in Legal Systems - with Applications to Climate Change Adaptation, 89 N.C. L. REV. 1373, 1381 (2011) [hereinafter Ruhl, General Design Principles] (offering examples of changes in the doctrine of nuisance in response to evolving understanding of the value of wetlands).

14. See infra Part II.A (arguing that climate change has rendered four assumptions of the ambulatory boundaries framework untrue). 
Using Florida law as an illustration, Part I of this paper sets forth the constitutional and common law that governs littoral property rights and defines those lands protected by the public trust as sovereign submerged lands. Florida is a state with a particularly high stake because of the length of its coastline, ${ }^{15}$ the significant effects it is already experiencing, ${ }^{16}$ the unique challenges it faces in responding to sea-level rise, ${ }^{17}$ and its beachtourism-dependent economy. ${ }^{18}$ Moreover, although each state's law is

15. Florida has 8,436 miles of coastline, surpassed only by Alaska. See NOAA, OfF. FOR Coastal Mgmt., General Coastline and Shoreline Mileage of the United States, https://coast.noaa.gov/data/docs/states/shorelines.pdf (last visited Nov. 30, 2017). Of these, 825 miles are sand beaches. Why Beach Restoration, Fla. DEP'T Envtl. PROT., https://floridadep.gov/wra/beaches-funding/content/why-beach-restoration (last updated Sept. 7, 2017). Seventy-five percent of Florida's population lives in coastal counties, and these counties generate $79 \%$ of the state's economic activity. Nathalie Baptiste, That Sinking Feeling: The Politics of Sea Level Rise and Miami's Building Boom, THE AM. PROSPECT (Feb. 19, 2016), http://prospect.org/article/sinkingfeeling-politics-sea-level-rise-and-miamis-building-boom.

16. Gary T. Mitchum, Fla. Climate Inst., Sea Level Changes in the Southeastern United STATES: PAST, PRESENT, AND FUTURE 5, 9 (2011), http://floridaclimateinstitute.org/images/rep orts/201108mitchum_sealevel.pdf. Reports in the popular press have highlighted in particular the problem often called vertical or "sunny day" flooding associated with monthly high tides or spring tides. See, e.g., Elizabeth Kolbert, The Siege of Miami, NEW YORKER, Dec. 21 \& 28, 2015, at 42,45 (reporting that Florida suffers from three significant effects of global climate change: sea-level rise, higher water tables, and extreme weather events).

17. The karst geology that produces vertical flooding limits the efficacy of seawalls, dikes, and other structures designed to keep water out along much of the coast. The damaging storm surges associated with the hurricanes to which Florida is vulnerable amplify the erosion caused by sea-level rise. The Southeast Florida Regional Climate Compact has estimated that, in Southeast Florida alone, as much as $\$ 4$ billion worth of real estate value will be inundated at one foot of sea-level rise, and as much as $\$ 31$ billion of value will be inundated at three feet of sea-level rise. SE. Fla. CLIMATE COMPACT Ctys., A Region Responds to Climate Change: Regional Climate Action Plan 9-10 (2012), http://www.southeastfloridaclimatecompact.org//wp-content/uploads/2014/09/regional-climate-actionplan-final-ada-compliant.pdf. ClimateCentral estimates that 2.4 million people and 1.3 million homes are within four feet elevation of the mean high water line in Florida. Ben Strauss, Florida and the Rising Sea, SURGING SEAS, http://sealevel.climatecentral.org/news/floria-and-the-rising-sea (last visited Nov. 30, 2017).

18. Tourism spending in Florida in 2015 amounted to $\$ 89.1$ billion, generating $\$ 5.3$ billion in tax revenue. An estimated 1.2 million Florida residents were employed by the tourism industry as of early 2016. Will Seccombe, Florida Tourism Generated \$89.1 Billion in Economic Impact in 2015, SUNSHINE MATTERS (Apr. 28, 2016, 11:40 AM) [hereinafter Florida Tourism], http://www.visitfloridablog.org/?p=15486. An estimated 106,585,000 tourists visited Florida in 2015. Id. A substantial portion of these visits Florida's beaches. See Fla. TAX Watch, InVesting in TOURISM: ANALYZING THE ECONOMIC IMPACT OF EXPANDING FLORIDA TOURISM 4 (2013), http://floridataxwatch.org/resources/p df/2013TourismFINAL.pdf. (“[A] 2011 Visit Florida Study found that 40 percent of all U.S. visitors [to Florida] reported beach and waterfront activities as one of their top activities when visiting Florida.”). Compared to the total 82.6 million tourism visitors in 2010, the seven leading Florida theme parks (four Walt Disney World, two Universal, and Busch Gardens) had a total of 33 million visitors. Christopher Thompson, Florida Tourism Industry Welcomed 82.6 Million Visitors in 2010, SunShine MATTERS (Feb. 16, 2011, 1:16 PM), www.visitfloridablog.org/?p=1573; Ray Oldakowski, Florida's Tourism Industry, AM. Ass'N GEOGRAPHERS NEWSLETTER (Nov. 8, 2013), http://news.aag.org/2013/11/floridas-tourism-industry/; see also CATANESE CTR., FlA. ATL. UnIV., 
unique, the broad contours of Florida's doctrine are similar to those of many other coastal states. ${ }^{19}$ Thus, the analysis can be readily adapted to apply to other coastal states as well. ${ }^{20}$ Drawing in part on the historical work done by Professor Sax, Part I closes by identifying the five primary rationales that justify application of the ambulatory boundaries framework: (1) de minimis non curat lex; (2) fairness; (3) protection of the public interest; (4) social utility/productivity of land; and (5) protection of littoral landowners' access to water. ${ }^{21}$

Part II identifies four doctrinally significant factual predicates for application of these doctrines that are absent in an era of sea-level rise. ${ }^{22}$ Unlike the historic change experienced along coastlines, sea-level rise is predictable, unidirectional, ongoing, geographically pervasive along the coast, and generally restricted to coastal areas. ${ }^{23}$ Both the changed physical reality associated with sea-level rise and the impact these changed facts have on the rationales for the common law framework undermine the legal justification for applying these rules in areas affected by sea-level rise.

Based on this analysis, the article suggests that in cases arising in an era of documented and scientifically predictable sea-level rise, common law courts should take account of the changed facts. In Part III, the paper presents two distinct approaches courts might take to adapt the law to the new coastal realities.

The first, more limited approach that courts might adopt is to continue applying the ambulatory boundaries framework while taking explicit account of the realities associated with sea-level rise. Courts might also consider how these realities affect the rationales underlying the ambulatory boundaries framework. In this approach, courts would continue to apply the doctrines, but better align their application with rationales that remain relevant in the context of predictable, ongoing, and pervasive sea-level rise.

The second, more comprehensive approach is to clear the debris of the ambulatory boundaries framework. This would leave two primary bodies of directly relevant law: (1) the law governing real property boundary

ECONOMICS OF BEACH TOURISM IN FLORIDA (2005), https://www.dep.state.fl.us/beaches/publications/ pdf/phase2.pdf (describing the importance of the tourism industry in Florida).

19. See Margaret E. Peloso \& Margaret R. Caldwell, Dynamic Property Rights: The Public Trust Doctrine and Takings in a Changing Climate, 30 STAN. ENVTL. L.J. 51, 109-19 (2011) (providing a useful summary of state legal doctrines related to public trust and littoral rights and a chart highlighting the areas of similarity and difference).

20. See id. (analogizing the summary to fit other coastal states).

21. See infra Part I.D (discussing rationales for ambulatory boundaries).

22. See infra Part II (discussing four factual assumptions: predictability; directionality; frequency and scope; and homogeneity of water bodies).

23. Sax, Rising Sea Levels, supra note 5, at 645. 
determinations and boundary and ownership changes; and (2) the law governing submerged lands and protecting the public trust. ${ }^{24}$ The ambulatory boundaries framework has historically supplanted this law and thus avoided the need to mediate the tension between them. ${ }^{25}$ However, this analysis suggests that courts can mediate this tension directly and effectively by removing the distorting impact of the archaic ambulatory boundaries framework.

Part III sketches how a court adopting either approach would analyze a boundary question, and identifies some of the critiques and concerns that each approach raises.

\section{BEACH LAW: Where SOVEREIGNTy LANDS MeEt LitTORAl Property RIGHTS}

The law of public and private property rights at the coastline will certainly become a more frequent and contentious battleground as the sea level rises and state and local governments respond to the resulting and anticipated changes. ${ }^{26}$ The uncertainty that surrounds property boundaries at the sea's edge, even without sea-level rise, makes coastal property rights a difficult and contentious terrain. ${ }^{27}$ The relatively high value of coastal property and the near certainty of coastal erosion make litigation over the private owners' rights and claims more likely. ${ }^{28}$

Erosion already affects a substantial part of Florida's coastline. ${ }^{29}$ Almost half of the linear extent of Florida's beaches have already been designated "critically eroded" and, therefore, eligible for restoration and

24. See infra Part III (expanding on doctrinal implications of sea-level rise).

25. See generally Lear, supra note 2, at 265 (explaining the history of riparian boundaries and how the framework has worked in place of land being put under public trust).

26. Doremus, supra note 3 , at $1105-10$.

27. Id. at $1105,1109$.

28. Id. at 1105-06. See, e.g., Deborah Wheeler, Walton Commission Votes in Favor of Public Beach Access, Nw. FlA. DAILY News [hereinafter Wheeler, Walton Comm'n], http://www.nwfdailynews.com/news/20161026/walton-commission-votes-in-favor-of-public-beachaccess (last updated Oct. 26, 2016) (highlighting the contention between a customary use ordinance and private property rights); CNN Wire Staff, Beachfront Homeowners Lose at Supreme Court, CNN (June 17, 2010, 5:22PM), http://www.cnn.com/2010/CRIME/06/17/scotus.property/index.html (detailing that "[t]he homeowners [in arguing Stop the Beach Renourishment] told the court the difference between beachfront and 'beach view'-from an aesthetic and financial point of view-is tremendous when property values are considered.”).

29. Fla. Dep’t of EnVtl. Prot., Critically Eroded Beaches in Florida 4 (August 2016) [hereinafter Critically Eroded], https://floridadep.gov/sites/default/files/CriticalErosionReport.pdf (reporting 411.2 miles of Florida's beaches as critically eroded and 93.5 miles as non-critically eroded). 
nourishment under the state beach management program. ${ }^{30}$ In developed areas, many private landowners are facing a one-way trend of erosion that may entail the loss of property and ultimately jeopardize any structures on the property. ${ }^{31}$ Florida's beaches face an uncertain future; both their existence and the public's right to enjoy those that survive are at risk.

Historically, there have been conflicts about property boundaries and the application of statutes, the public trust doctrine, and other common law principles to Florida's beaches and beach-adjacent lands and waters. ${ }^{32}$ However, perhaps because the conflicts were the exception rather than the rule, most of those who have a stake in Florida's beaches-coastal landowners, beach-tourism-dependent businesses, state and local government agencies, and even members of the public who use the beaches - could afford to be somewhat lax in their understanding of the scope of the various parties' rights and duties. ${ }^{33}$ Moreover, because of the dynamic nature of the coastline and coastal property boundaries, property owners and members of the beach-going public are frequently unaware of the location of the littoral property boundary at any given time. ${ }^{34}$ Even if they fully understand the legal and factual basis for determining where the boundary lies and the circumstances under which it might change, applying

30. As of 2016, 61\% of Florida beaches (504.7 miles of 825 total miles) were eroding: 411.2 miles were critically eroded and 93.5 non-critically eroded. FLA. DEP’T OF ENVTL. PROT., supra note 29. Since 1998, the state has spent $\$ 626.6$ million under its cost-sharing program for local and federally authorized beach restoration and nourishment, pursuant to FLA. STAT. § 161.101 (2012). Under the statute each level of local government typically contributes roughly a third of the cost. This funding has gone to restore and maintain almost 56\% of the state's critically eroded beaches. Beach Management Funding Assistance (BMFA) Program, FLA. DeP’T EnVTL. Prot., https://floridadep.gov/wra/beachesfunding (last visited Nov. 30, 2017). However, as the recent experience with Hurricane Matthew illustrated, these efforts can be quickly washed away by a single major storm, leading to increasing calls to reevaluate the commitment to this strategy. See Robert S. Young, The Beach Boondoggle, Opinion, N.Y. TIMES (Oct. 12, 2016) https://www.nytimes.com/2016/10/12/opinion/the-beachboondoggle.html?_r=0 (detailing the costs of beach renourishment and urging prioritization of federal funding to create appropriate incentives that better align with the broader interest of all taxpayers).

31. Thomas K. Ruppert, Eroding Long-Term Prospects for Florida's Beaches: Florida's Coastal Construction Control Line Program, 1 SEA GRANT L. \& POL’y J. 65, 67-68 (2008).

32. See, e.g., Walton County v. Stop the Beach Renourishment, Inc., 998 So. 2d 1102, 1109-14 (Fla. 2008) (explaining the relationship between public and upland owners under common law principles and Florida's statutes).

33. See, e.g., Beach Access, supra note 1 (describing the public's lack of knowledge regarding actions that restrict beach access).

34. See id. (highlighting the public's confusion over the precise location of property boundaries); see also Deborah Wheeler, Update: Walton Commissioners Vote to Remove Signs, Ropes from Beach, WALTON SUN (Mar. 23, 2016) [hereinafter Walton Update], http://www.nwfdailynews.com/news/20160615/update-walton-commissioners-vote-to-remove-signs-rop es-from-beach (describing the public's anger over the municipality regulating public spaces that were believed to be private property). 
these rules is a complex, uncertain, and data-intensive inquiry in many settings. ${ }^{35}$

Even courts resolving disputes over public and private rights in the contested coastal zone have sometimes been far from rigorous in their analyses, resolving disputes with simplistic conclusions about causation, ${ }^{36}$ and paying insufficient attention to legally important geographic features in the area. ${ }^{37}$ As the battle lines are drawn more frequently, far more technical discussions about the mean high-water line, the foreshore between mean low- and high-water lines, and the area between the mean high-water line and the vegetation line have become essential. ${ }^{38}$

\section{A. Sovereign Submerged Lands and the Public Trust}

Florida common law, like the law of many states, recognizes three zones along the coast that have distinct characteristics under real property law: submerged lands, foreshore, and dry sand beach. ${ }^{39}$ An important, albeit dynamic, boundary demarcation in this zone is the mean high-water line (MHWL), a line determined based on the previous 19 years of mean high-

35. Given the arcane nature of the common law, such knowledge is not likely to be widely held. See infra pp. 11-14 (discussing determination of littoral property boundaries under Florida common law).

36. See Walton County, 998 So. 2d at 1106, aff'd sub nom. Stop the Beach Renourishment, Inc. v. Fla. Dep’t of Envtl. Prot., 560 U.S. 702, 703 (2010) (affirming the Florida Supreme Court's decision). The Florida Supreme Court states that under Florida law, hurricanes are "generally considered avulsive events." Walton County, 998 So. 2d at 1116. This seems an intuitively reasonable generalization. However, the very cases the court cites for this proposition reflect the frequent factual complexity of the impacts of hurricanes, not to mention the interaction of these impacts with subsequent erosion or accretion in the same areas. See, e.g., Ford v. Turner, 142 So. 2d 335, 339 (Fla. Dist. Ct. App. 1962) (involving an argument that the property was cut through by a hurricane, but was subsequently covered by an accretion to the plaintiff's property).

37. See, e.g., City of Daytona Beach v. Tona-Rama, Inc., 294 So. 2d 73, $79-80$ (Fla. 1974) (Boyd, J., dissenting) (referring generically to "beaches" as though the term were self-defining). The division in the court in that case highlights the lack of clarity on how broad an area the courts should consider in determining both whether customary rights attach and whether a given activity interferes with them.

38. See generally Ruhl, Climate Change Adaptation, supra note 13, at 377 (stating that one of first macro effects of climate change will be a transition in the vegetation line because of sea-level rise and reduced rainfall); see also Peloso \& Caldwell, supra note 19, at 58 (stating that, in Texas and New Jersey, public trust governs all the way to the first line of vegetation); Christie, supra note 3 , at 46,47 , 50, 54-56 (providing examples of how and why physical markers that determine private and state property rights along the coast must be scrutinized carefully as effects of climate change become more prolific).

39. See Peloso \& Caldwell, supra note 19, at 60 (summarizing state legal doctrines related to public trust and littoral rights). 
water lines. ${ }^{40}$ The Florida constitution, state statutes, and common law establish that the state holds lands below the MHWL in trust for the public. ${ }^{41}$ These lands include two zones with distinct qualities and legal significance: sovereign submerged lands ${ }^{42}$ and the foreshore (or wet sand beach), which is the sandy area between the MHWL and the mean lowwater line. ${ }^{43}$ The third zone, the dry sand beach, is less well defined, but generally describes the area between the MHWL and the vegetation line. ${ }^{44}$ Florida Statute $\S 164.54$ defines the term "beach" generally as extending from the seaward boundary of the foreshore (i.e., the low water mark) to "the place where there is marked change in material or physiographic form, or to the line of permanent vegetation, usually the effective limit of storm waves" (i.e., the vegetation line). ${ }^{45}$

In describing the roots of the state's title to the submerged lands under navigable waters, the Florida Supreme Court has noted repeatedly that these lands are held by the state:

[N]ot for purposes of disposition to individual ownerships, but such title was held in trust for all the people of the states respectively, for the uses afforded by the waters as allowed by the express or implied provisions of law, subject to the rights surrendered by the states under the federal Constitution. ${ }^{46}$

Among the uses protected by the public trust in navigable waters, sovereign submerged lands, and the foreshore are navigation, fishing, bathing, ${ }^{47}$ and activities for commerce. ${ }^{48}$ The state has authority to regulate these uses and

40. FLA. STAT. §§ 177.27(14), (15) (2016) (defining “mean high water” and “mean high-water line”).

41. FLA. CONST. art. X, § 11; FLA. StAT. § 177.28(1) (1974) (providing that the mean highwater line along coastlines is the boundary between state and privately owned land); Walton County, 998 So. 2d at 1109 (recognizing that the state holds land seaward of the MHWL in trust for the public); Stop the Beach Renourishment, Inc., 560 U.S. at 707 (recognizing that in Florida, the state owns the foreshore and submerged lands beneath navigable waters in trust for the public).

42. FLA. CONST. art. X, § 11 .

43. Id.; see White v. Hughes, 190 So. 446, 449 (Fla. 1939) (noting Florida law that recognizes area between the high- and low-water marks as beach); see also Brickell v. Trammell, 82 So. 221, 226 (Fla. 1919) (describing which lands and navigable waters are property of the state or of its people).

44. See Common Law \& Statutes, FlA. SEAGRANT, https://www.flseagrant.org/wateraccess/co mmon-law-statutes/ (last visited Nov. 30, 2017) (illustrating the location of the dry sand beach relative to the mean high tide).

45. FLA. STAT. § 161.54 (2011).

46. Broward v. Mabry, 50 So. 826, 829 (Fla. 1909).

47. White, 190 So. at 449.

48. See Brickell, 82 So. at 226 (listing navigation, fishing, and other useful purposes in addition to commerce). 
a duty to do so under both the common law and the state constitution, ${ }^{49}$ subject to Congress's superseding authority to regulate commerce. ${ }^{50}$

The MHWL thus defines the landward reach of shorelands and waters subject to the public trust. Florida's courts have repeatedly emphasized the primacy of the government's duty to use lands below the MHWL for proper public uses, ${ }^{51}$ consistent with the state's duty under Article X, Section 11 of the state constitution. ${ }^{52}$

\section{B. Private Lands and Littoral Rights}

In general, the seaward boundary of property that extends to the ocean and other tidal waters, such as the Gulf of Mexico and the Straits of Florida, is the MHWL. ${ }^{53}$ Property that extends to the MHWL of a tidal water body is typically called "littoral" property to distinguish it from property on flowing water bodies such as rivers or navigable streams, which are designated by the more general term riparian property. ${ }^{54}$ Littoral and other

49. Walton Cty. v. Stop the Beach Renourishment, Inc., 998 So.2d 1102, 1110 (Fla. 2008) (quoting FLA. CONST. art. II, § 7(a)) (“[I]t shall be the policy of the state to conserve and protect its natural resources and scenic beauty. Adequate provision shall be made by law for the abatement of air and water pollution and of excessive and unnecessary noise and for the conservation and protection of natural resources.”).

50. Walton County, 998 So. 2d at 1109-10 (quoting Brickell, 82 So. at 221).

51. See, e.g., Broward v. Mabry, 50 So. 826, 829, 830 (Fla. 1909) (describing scope of public trust in a case involving a navigable lake); Brickell, 82 So. at 226 (explaining that states have the right to uphold and maintain navigable waters).

52. This section provides:

The title to lands under navigable waters, within the boundaries of the state, which have not been alienated, including beaches below mean high water lines, is held by the state, by virtue of its sovereignty, in trust for all the people. Sale of such lands may be authorized by law, but only when in the public interest. Private use of portions of such lands may be authorized by law, but only when not contrary to the public interest.

FLA. CONST. art. X, § 11.

53. See Christie, supra note 3, at 46, 48-49 (recognizing that under Florida law, the location of the mean high-water line determines private and state property rights along the coast); see also FLA. STAT. § 177.28(1) (1974) (stating that the mean high-water line is the seaward property boundary).

54. The term littoral property is also used to describe property bounding navigable lakes. In general, the common law doctrines applied to littoral property are the same as those that apply to riparian property that bounds a navigable stream, river or other flowing water. See, e.g., 4 HERBERT THORNDIKE TifFANy, THE LAW OF REAL Property § 1219 (3d ed. 2016) (using littoral and riparian rights interchangeably in describing the doctrine of accretion). Many of the basic principles related to boundaries and riparian rights were adopted in cases involving a riparian context. Id. The term "riparian rights" is typically used to describe the special rights accorded both littoral and riparian property owners. See Bd. of Trs. of the Internal Improvement Tr. Fund v. Sand Key Assocs., Ltd., 512 So. 2d 934, 936 (Fla. 1987) (recognizing that "[c]ases and statutes, however, have used 'riparian owner' broadly to describe all waterfront owners”). 
riparian landowners have special riparian rights in addition to sharing with the public the right to fishing, bathing, navigation, and commerce. ${ }^{55}$ In Florida, these include the right of access to and from the water, the right to retain an unobstructed view of the water, the right to use the water, and the right to protect the abutting property from trespass. ${ }^{56}$ In addition, littoral landowners have what the Florida Supreme Court has recently characterized as "contingent, future" rights under Florida common law: the right to acquire title to land exposed or created as a result of the operation of the common law doctrine of accretion. ${ }^{57}$ The Florida Supreme Court early on described the exclusive rights of a riparian owner as "such as are necessary for the use and enjoyment of his abutting property and the business lawfully conducted thereon; and these rights may not be so exercised as to injure others in their lawful rights." 58

\section{The Dynamic Boundary and Its Legal Significance}

Because the three zones noted above-submerged lands, the foreshore, and the dry sand beach-are defined with reference to the ebb and flow of the tides, their boundaries, and indeed their very location, can change as the level of the tides change. ${ }^{59}$ The MHWL is calculated over a period of 19

Although many of the same principles are applied similarly in the riparian and littoral context, there are some points of divergence. See TifFANY, supra §§ 1227-1229.1 (discussing separate principles for lakebeds, islands, and seashores). Courts may consider the littoral context significant for a variety of reasons. Moreover, the littoral context raises unique issues and challenges, including issues related to beach restoration and nourishment, and specialized statutory provisions that govern coastal areas. E.g., Walton County v. Stop the Beach Renourishment, Inc., 998 So. 2d 1102, 1105-07 (Fla. 2008) (involving a constitutional challenge aiming to stop Walton County from proceeding with a beach-renoursishment project undertaken pursuant to a Florida statute). Because this paper focuses on sea-level rise, it will primarily discuss littoral property and the law related to littoral lands without noting the exceptions, where these rules may differ from those applicable in other riparian contexts.

55. Walton County, 998 So. 2d at 1111.

56. Id.; Ferry Pass Inspectors' \& Shippers' Ass'n v. White’s River Inspectors' \& Shippers' Ass'n, 48 So. 643, 644-45 (Fla. 1909). The right to an unobstructed view of the water is not as common in other states as are the other riparian rights. See RoBIN Kundis CraIG, ET. AL., WATER LAW 37 (2017) (stating that only a small number of states, which includes Florida, recognizes a riparian right to an unobstructed view).

57. See Walton County, 998 So. 2d at 1112 (noting that the right to acquire title to land exposed or created by the doctrine of accretion is different from other riparian rights because it is a contingent future right, not an easement).

58. Ferry Pass Inspectors' \& Shippers' Ass'n, 48 So. at 644-45.

59. See Frank E. Maloney \& Richard C. Ausness, The Use and Legal Significance of the Mean High Water Line in Coastal Boundary Mapping, 53 N.C. L. REv. 186, 195, 197 (1974) (explaining that coastal boundaries are defined by the average rise and fall of the tide, and that tidal characteristics vary from place to place). 
years, ${ }^{60}$ which reduces but does not eliminate the instability and uncertainty associated with what is a fundamentally dynamic boundary ${ }^{61}$ Although the mean averages out the changes in the tides, the boundary can still fluctuate as much as the vagaries of the oceans and the common law legal framework dictate. ${ }^{62}$

Several different processes can occur to change the relative location of the dry sand beach, the foreshore, and submerged lands, all of which have potential impact on the extent of the lands subject to the public trust and private ownership, respectively. ${ }^{63}$ First, the sea can deposit sand or other alluvium on areas that were previously part of the submerged lands or foreshore, both held in public trust. ${ }^{64}$ This may create dry land below the old MHWL in areas that were previously submerged lands or foreshore. ${ }^{65}$ Over time, such a change may cause the MHWL to move seaward. Second, the sea can recede, leaving areas of the submerged lands or foreshore dry. ${ }^{66}$ As with the deposit of alluvium, this can transform water into land and will eventually cause the MHWL to move seaward. ${ }^{67}$ Third, the sea can erode or submerge land, transforming areas that were previously above the MHWL (and therefore considered dry land) into foreshore or submerged lands. ${ }^{68}$ It can also transform the foreshore into submerged lands. This does not have significant implications for ownership or public rights, since the state holds both in trust for the public. ${ }^{69}$ Each of these processes can occur naturally, or as a direct or indirect result of human actions, such as filling, draining, or building structures like groins, jetties, or sea walls. ${ }^{70}$

60. Fla. STAT. § 177.27(14) (1998); Tidal Datums, NOAA TIDES \& CuRRENTS, https://tidesandcurrents.noaa.gov/datum_options.html (last updated Oct. 15, 2013).

61. See Maloney, supra note 59, at 196 (explaining that determining boundaries like the MHWL follows the moon's 18.6 year nodal cycle, ultimately reducing the amount of variation).

62. See FlA. STAT. § 177.28(2) (1974) (stating that the legal significance of the MHWL as the boundary between sovereign submerged lands and adjacent private lands "shall [not] be deemed to modify the common law of this state with respect to the legal effects of accretion, reliction, erosion, or avulsion”).

63. See Lear, supra note 2, at 266-70 (explaining five situations where dynamic shoreline boundaries were litigated).

64. Id. at 276.

65. Id.

66. Sax, Rising Sea Levels, supra note 5, at 642.

67. Id.

68. As one court aptly noted, submersion and erosion are the reverse of the processes that deposit alluvium, and if slow and imperceptible, they are subject to application of the same legal principle. Mun. Liquidators v. Tench, 153 So. 2d 728, 730 (Fla. Dist. Ct. App. 1963).

69. See Sax, Accretion, supra note 4, at 352 (explaining that when land is submerged, public ownership moves landward to the new water's edge); see also FLA. Const. art. X, § 11 (providing that submerged lands belong to the state).

70. Perhaps because up until the present, there has been only modest increase in sea level, case law and commentary do not generally reference submersion of dry land without erosion. Any such 
In Florida, as in many jurisdictions, the law permits the seaward boundary of littoral property to change in circumstances when the line between water and dry land moves. ${ }^{71}$ Florida, like many jurisdictions, distinguishes between gradual and imperceptible changes to this boundary on the one hand and sudden and dramatic changes on the other. ${ }^{72}$ Gradual changes are termed accretion, reliction (known also by the more archaic term dereliction), or erosion, depending on which of the three processes described above is involved. ${ }^{73}$ Sudden changes in either direction are generally described as resulting from avulsive events. ${ }^{74}$ The term "avulsion" is used generically to indicate a dramatic shift in the location of water, whether the avulsive event causes a submersion of dry property, a deposit of alluvium that transforms submerged land or the foreshore to dry land, or a rapid withdrawal of water. ${ }^{75}$ Under the applicable legal doctrine, very different consequences result from gradual and imperceptible changes following accretion, reliction, and erosion than from similar changes following an avulsive event. ${ }^{76}$

Florida is perhaps fortunate to have the clarity of a recent decision by the state Supreme Court, affirmed by the U.S. Supreme Court, which included a review of the state's basic property law as it relates to the dynamic shoreline. ${ }^{77}$ In Walton County v. Stop Beach the Renourishment,

change over time will likely cause erosion, as well. This paper will use the term erosion to encompass submersion, as well. However, were the submersion of dry land to be solely the result of a dramatic and sudden event, it might be best described as flooding or submersion. Such events would likely be covered by the doctrine of avulsion rather than accretion/erosion.

71. See Walton County v. Stop the Beach Renourishment, Inc., 998 So. 2d 1102, 1113 (Fla. 2008) (stating that the legal effect of changes in the boundaries of shorelines depends on the speed of the change); see also Katrina M. Wyman \& Nicholas R. Williams, Migrating Boundaries, 65 FLA. L. REV. 1957, 1968-69 (2013) (stating that loss of land under the doctrine of avulsion does not change the preexisting mean high-water line).

72. See Walton County, 998 So. 2d at 1114 (Fla. 2008) (citing Bd. of Trs. of the Internal Improvement Tr. Fund v. Sand Key Assocs., Ltd., 512 So. 2d 934, 936 (Fla.1987)) (explaining the difference between gradual and sudden changes); TIFFANY, supra note 54, § 1219; see also Peloso \& Caldwell, supra note 19, at 114 (noting specific rights of littoral owners in Florida).

73. Lear, supra note 2, at 265. In order to distinguish various scenarios, this article will use the terms accretion, reliction, and erosion to describe relevant physical processes. The article will also frequently use the term accretion to describe the legal doctrine that applies in cases of gradual erosion and reliction. Therefore, although this paper will focus primarily on the doctrine of erosion, it will sometimes refer to the doctrine of accretion/erosion, although doctrinal discussions often refer only to accretion and avulsion, and ignore erosion. This paper will generally omit reference to reliction because reliction is infrequently implicated in an era of sea-level rise.

74. Wyman \& Williams, supra note 71 , at 1970.

75. Id.

76. Sax, Accretion, supra note 4, at 311.

77. See generally Walton County, 998 So. 2d at 1105 (rejecting challenges to the constitutionality of the Beach and Shore Preservation Act, a Florida statute under which restoration and re-nourishment of almost half of the state's beaches is ongoing). 
Inc., the Florida Supreme Court reviewed and reiterated the meaning of these important common law doctrines. ${ }^{78}$ It summarized the legal consequences for the littoral property boundary of these different processes. ${ }^{79}$

Accordingly, under the doctrines of erosion, reliction, and accretion, the boundary between public and private land is altered to reflect gradual and imperceptible losses or additions to the shoreline. In contrast, under the doctrine of avulsion, the boundary between public and private land remains the MHWL as it existed before the avulsive event led to sudden and perceptible losses or additions to the shoreline. ${ }^{80}$

The doctrines of accretion and erosion developed as an exception to the common law property rule requiring a deed transferring title in order to change a property boundary. ${ }^{81}$ Under Florida law, changes are presumed to be caused by gradual accretion, erosion, or submersion absent proof of an avulsive event. ${ }^{82}$ Thus, the accretion doctrine, pursuant to which the boundary moves with the gradually shifting sands, represents the default rule. ${ }^{83}$ When rising seas or erosion change the MHWL, property boundaries are subject to change as well, unless evidence is offered to sustain the conclusion that the change was caused by an avulsive event. ${ }^{84}$ Moreover,

78. Id. at $1109-14$.

79. Id.

80. Id. at 1114 (internal citation omitted).

81. See Sax, Accretion, supra note 4, at 311-12 (explaining that in the 1600s, transfer of accreted from sovereign to subject was exceptional and justified by the fact that the change was so minimal as to be insignificant).

82. In Municipal Liquidators $v$. Tench, a district court of appeals in Florida stated that:

[T] $]$ here is a presumption of accretion or erosion as against avulsion. As stated in

Gubser v. Town, the law presumes, in the absence of evidence to the contrary, that changes to riparian land occur "by accretion, and not by a sudden and violent force.” Further, "[t]he person who claims the land under the water has the burden of showing that it caved off suddenly."

Mun. Liquidators, Inc., v. Tench, 153 So. 2d 728, 731 (Fla. Dist. Ct. App. 1963) (internal citations omitted) (quoting 1 Henry PhILIP Farnham, The LAW OF WATERs and Water Rights (The Lawyers' Coop. Publ'g Co. (1904), reprinted in 1 HENRY PHILIP FARNHAM, THE LAW OF WATERS AND WATER RIGHTS 331-332 (The Lawbook Exch., Ltd., 2006)). Professor Sax points out some notable cases in which courts have strained to find accretion where it is hard to conclude that the change was imperceptible as it occurred. Sax, Accretion, supra note 4, at 351-53. However, as the stakes increase for landowners with sea-level rise, landowners' challenges will likely put some pressure on courts that have applied an almost irrefutable presumption of accretion in the past.

83. See, e.g., Missouri v. Nebraska, 196 U.S. 23, 34-36 (1904) (finding that the doctrine of accretion governs absent proof of avulsion).

84. See Mun. Liquidators, 153 So. 2d at 731 (holding that the party claiming the benefit from avulsion has the burden of proving avulsion occurred). 
even when a court finds that an avulsive event caused the change, the doctrine only accords the landowner the "right to reclaim" the land "within a reasonable time." ${ }^{85}$ Although rarely elaborated, this limitation seems best explained by the fact that: (1) submerged lands are presumed to be of limited value to landowners; and (2) submerged lands serve important public interests under the public trust that will ultimately prevail unless the landowner asserts the right to reclaim. ${ }^{86}$

In the language quoted above, the Florida Supreme Court summarized the legal doctrines by identifying the diagnostic fact that distinguishes the setting in which the two doctrines apply: the speed of the change. ${ }^{87}$ However, it is important to note that a change and the speed of the change do not resolve the legal question. ${ }^{88} \mathrm{~A}$ careful review of case law reveals that proper application of these principles requires consideration of a number of additional factors. As Joseph Sax notes in his excellent history of the doctrines, the mere fact of a natural change did not automatically produce a change in title. ${ }^{89}$ The boundary changes only if a court, after considering relevant factors or justifications, determines that the accretion doctrine should apply. ${ }^{90}$ In its opinion in Walton County, the Florida Supreme Court explicitly adopted this approach as well. ${ }^{91}$ Thus, the rationales or justifications for applying the ambulatory boundaries framework play an important role in the doctrines' application. Likewise, the facts relevant to these rationales have doctrinal significance. The next section examines these rationales in detail below.

85. See, e.g., Walton County v. Stop the Beach Renourishment, Inc., 998 So. 2d 1102, 1117 (Fla. 2008) (stating that the doctrine of avulsion recognizes owner's "right to reclaim the lost land within a reasonable time"); see also Trs. of Freeholders \& Commonalty of Town of Southampton v. Heilner, 84 Misc. 2d 318, 331 (N.Y. Sup. Ct. 1975) (holding that the property owner had the right to reclaim land that had become suddenly submerged, but not the portion lost through erosion).

86. See Walton County, 998 So. 2d at 1117 (conditioning the ability to reclaim on reasonable time and citing earlier case allowing self-help in doing so); Mun. Liquidators, 153 So. 2d at 731 (holding that the party claiming the benefit from avulsion has the burden of proving avulsion occurred).

87. Walton County, 998 So. 2d at 1117.

88. See Sax, Accretion, supra note 4, at 324 (requiring that claimants to accreted land show legal justification for a change in title).

89. Id. at 324-25.

90. Id.

91. Walton County, 998 So. 2d at 1118-19 (finding that none of the four rationales for according a right to accretion applied in the context of the case). 


\section{The Rationales Supporting the Doctrines of Accretion/Erosion and Avulsion}

Joseph Sax's analysis of the historical roots of the common law doctrines illustrates the change over time in values used to justify the contours of these common law doctrines. ${ }^{92}$ Sax's analysis also shows the doctrines' lack of coherence with the rationales that historically justified their use. ${ }^{93}$ Notwithstanding these apt critiques, certain justifications for applying the doctrines have endured throughout most of their history. These rationales are: (1) the minimal impact of boundary changes to property interests (the de minimis rationale); (2) reciprocity or fairness; (3) protection of the sovereign's (or public) interest; and (4) social utility or productive use of land. ${ }^{94}$ These four rationales appear fairly consistently in the earliest British cases. However, a fifth rationale or justification has become central and arguably dominant in American common law: protection of the littoral landowner's right of access to the water. ${ }^{95}$

In its decision in Walton County, the Florida Supreme Court considered all five key rationales to justify its decision. ${ }^{96}$ In deciding that the Beach and Shore Preservation Act did not deprive littoral owners of the riparian right to receive future accretions, the Court concluded that none of the rationales for allowing accretions to benefit a littoral property owner supported applying the doctrine to the plaintiff's context. ${ }^{97}$ The Court surveyed four core rationales for allowing the accretion doctrine to change property boundaries: de minimis non curat lex; reciprocity; productive use of land; and preservation of the riparian right of access to water. ${ }^{98}$ It also noted that the right to accretion arises from "a rule of convenience intended

92. See generally, Sax, Accretion, supra note 4, at 334-42 (exploring the evolution over time of the rationales offered, including rationales that have been abandoned, such as the "lost boundary" rationale, and newer rationales, such as maintaining water access). The analysis here distills the common components of the rationales that endure to the present.

93. Id. at 337 (describing how, in the 19th century, English jurisprudence retained the accretion/avulsion doctrine when all the rationales that had supported the doctrines had been abandoned or rejected).

94. Id. at 330.

95. See Sax, Accretion, supra note 4, at 347-49 (describing the emergence of water access as primary rationale in modern United States cases); PowELL, supra note 6, §66.01[3] n.36 (citing numerous cases and describing water access as "[t]he most persuasive and fundamental rationale" for accretion).

96. Walton County, 998 So. $2 \mathrm{~d}$ at $1118-19$.

97. Id. at 1114-15, 1118 (discussing de minimis, reciprocity, and productive use of land and water access, and describing the legal framework as balancing public and private interests).

98. Id. at 1114 (quoting Bd. of Tr. of Internal Improvement Tr. Fund v. Medeira Beach Nominee, Inc., 272 So. 2d 209, 212-13 (Fla. Dist. Ct. App. 1973)). 
to balance public and private interests ....”99 It identified the rationale for applying the avulsion doctrine as the need to mitigate the hardship of drastic shifts in title resulting from sudden and unexpected changes in the shoreline. ${ }^{100}$ On the facts before it, the Court concluded that "[n]one of [the] doctrinal reasons [for applying the rule of accretion] apply here.” 101

The relationship between these rationales and the slow/fast distinction that determines which rule applies is subtle and not always obvious. Some of the rationales seem equally applicable whether the change is slow or fast. In other words, they do not always justify the preference for applying one rule over the other. Most of the time, they justify having a distinct rule in the coastal boundaries context instead of applying background common law property rules that generally govern boundaries. Some of the rationales support both rules for different reasons. This part briefly describes each of the five rationales, both as each appears in the early British cases and in recent United States case law. Part II then explores the connection between these rationales and the changed factual reality presented in the context of sea-level rise.

\section{De Minimis Non Curat Lex}

Sax's history illustrates that the earliest cases applying the ambulatory boundaries framework relied on the fact that the volume of acreage involved was too small to concern the sovereign as a rationale for applying the special legal framework. ${ }^{102}$ This rationale justified depriving the sovereign of lands in cases of accretion. ${ }^{103}$ Given that the acreage involved in some of the early cases offering this rationale is arguably substantial, ${ }^{104}$ Sax suggests that perhaps the de minimis concept is contextual and best understood as referring not to the acreage assessed in the abstract, but to the impact on the sovereign's overall interest in controlling the coast and submerged lands. ${ }^{105}$ In that light, even hundreds of acres might be considered to be of little significance to the king's interest, which largely lay in preserving public access to navigation and protecting strategic military interests in the coast during that era. ${ }^{106}$ Another possible reading is that the sum of the lands likely to be affected by applying the doctrines was

99. Id. at 1118.

100. Id. at 1114 .

101. Id. at 1118.

102. Sax, Accretion, supra note 4, at 312, 324 (referring to de minimis non curat lex).

103. Id.

104. See id. at 331 (discussing a case that involved property measuring 453 acres).

105. Id. at 329.

106. Id. at 325. 
de minimis because cases of significant accretion and erosion were rare. ${ }^{107}$ Modern cases continue to offer de minimis impacts as a rationale justifying application of the ambulatory boundaries framework. ${ }^{108}$

\section{Fairness}

From the earliest British cases through to the modern era, fairness has appeared as a core value to which courts have looked to justify accretion and avulsion. ${ }^{109}$ In cases of accretion, courts justify awarding newly exposed or created land to riparian landowners on a theory of "reciprocity" that is grounded in fairness. ${ }^{110}$ Riparian landowners deserve to benefit from the gains of a receding sea, as the argument goes, because they bear the special costs and risks of inundation, as well. ${ }^{111}$ Fairness also appears, albeit in a slightly different form, as a justification for the avulsion doctrine. ${ }^{112}$ The relative hardship produced by a dramatic shift in title resulting from a sudden event is a theme in both older and modern cases. ${ }^{113}$ Allowing the boundary to remain unchanged permits the landowner to reclaim the land if reclamation is feasible and can be accomplished within a reasonable

107. Id.

108. See, e.g., Walton County v. Stop the Beach Renourishment, Inc., 998 So. 2d 1102, 1118 ("[C]ritically eroded shorelines can hardly be characterized as trifles with which the law does not concern itself.”); TIFFANY, supra note 54, § 1219 n.4 (citing State Eng’r of Nev. v. Cowles Bros., Inc., 478 P.2d 159, 162 (Nev. 1970)) (involving reliction). But see Powell, supra note 6, § 66.01 n.24 (stating that justification has received little modern support.).

109. Sax, Accretion, supra note 4, at 325, 342.

110. Id. at $308,320$.

111. Id. at 320, 321-22 (discussing the Abbot of Ramsey's case and Callis on Sewers, respectively). In the Abbot of Ramsey's case, the reciprocity is expressed in terms of the landowner's marsh, which "sometimes shrinks, through the influx of the sea, and at other times is enlarged by the flowing out of the sea...." Id.at 318. See also id. at 340 n. 199, 341 (discussing the 19th Century American treatise writer Roger Angell's incorporation of the reciprocity rationale to support the doctrine of accretion, and identifying Hall's adoption of Blackstone's three rationales for accretion, one of which was reciprocity). More modern cases include Bonelli Cattle Co. v. Arizona, 414 U.S. 313, 329 (1973) (describing a "compensation theory" that justifies awarding riparian landowner accretions); Banks v. Ogden, 69 U.S. 57, 67 (1864) (providing two different reasons-coastal property owners should benefit from a receding sea); County of St. Clair v. Lovingston, 90 U.S. 46, 57 (1874) (holding that a riparian owner has a fair right to avulsion); Maunalua Bay Beach Ohana 28 v. State, 222 P.3d 441, 445 (Haw. Ct. App. 2009) (summarizing compensation or equity theory).

112. Sax, Accretion, supra note 4, at 336.

113. See id. at 324-25 (suggesting that the gradualness of the process of change may diminish the sense of loss); Bonelli Cattle, 414 U.S. at 327 (stating that the rationale for avulsion is to mitigate the hardship that a shift in title resulting from a sudden shift in a river would cause); Walton County, 998 So. 2d at 1113-14; see also PoweLL, supra note 6, § 66.01[3] n. 42 (citing Cox v. F-S Prestress, Inc., 797 So. 2d 839, 843-44 (Miss. 2001)). 
time. ${ }^{114}$ Given fairness's use as a justification for both a static and a moving boundary, this rationale does not provide a coherent justification for treating sudden events differently from slow and imperceptible ones. However, it can perhaps be understood as justifying the deviation from the traditional principles governing real property boundary law.

\section{Protection of the Sovereign/Public Interest}

Britain implicitly recognized protection of the sovereign's interest as an important consideration fairly early, although in some cases it was honored in the breach. ${ }^{115}$ Sax notes that by the 1600 's, commentators in England recognized the importance of the sovereign's interest in land at the water's edge. ${ }^{116}$ In several cases recounted by Callis, courts refused to allow the landowner to claim title to new land in cases of extensive reliction because of the impact on the sovereign. ${ }^{117}$ Lord Hale, and later British commentators and decisions, regarded the avulsion doctrine as aligned with the sovereign's strategic interests in the shoreline because the avulsion doctrine left the boundary in place when sudden and substantial changes occured. ${ }^{118}$ Callis and Blackstone acknowledged this interest even when finding it unaffected in some cases where the de minimis nature of the sovereign's loss justified applying the accretion doctrine. ${ }^{119} \mathrm{~A}$ few later cases emphasize the sovereign or public interest, ${ }^{120}$ but modern U.S. courts

114. See, e.g., Walton County, 998 So. 2d at 1117 (stating that the doctrine of avulsion recognizes owner's "right to reclaim the lost land within a reasonable time"); see also Trs. of Freeholders \& Commonalty of Town of Southampton v. Heilner, 84 Misc. 2d 318, 331 (N.Y. Sup. Ct. 1975) (holding that the property owner had the right to reclaim the land that had become suddenly submerged, but not the portion lost through erosion).

115. Sax, Accretion, supra note 4, at 312, 324.

116. Id. at 312 n.29.

117. Id. at 322 (describing the cases of Brown and Bushey). This was recast by Hall in his 1853 essay to emphasize the de minimis amount of land. In Hall's view, imperceptibility of the change provided a proxy for evidence of lack of value and hence a conclusion of negligible impact on the sovereign. Id.

118. Id. at 325, 327. This leaves unaddressed the risk of slow but substantial change, which could adversely affect the sovereign's interest, but presumably not in such a dramatic fashion, hence providing the sovereign time to adapt or respond to the changing situation. See id. at $332 \mathrm{n} .149$ (discussing the House's of Lords explicit consideration of the lack of harm to the sovereign's interest in Lord Yarborough's case, awarding 453 acres formed by accretion to the littoral landowner, and distinguishing cases in which large areas of sovereign lands are exposed suddenly); id. at 342 (discussing three rationales for the rule of accretion in Hall's Essay on the Rights of the Crown and the Privileges of the Subject in the Sea Shores of the Realm).

119. Id. at 312, 324.

120. Bonelli Cattle Co. v. Arizona, 414 U.S. 313, 328 (1973) (finding the rationale for avulsion not applicable because the river was too wide and shallow to permit navigation, thereby limiting the state's interest in the property). In Corpus Christi v. Davis, a Texas appellate court declined to determine the question of the applicability of the doctrine of avulsion to tidelands because of its 
often focus on the public trust doctrine and the sovereign's duties as trustee of submerged lands as the legal grounding for considering the protection of the public interest in these cases. ${ }^{121}$

\section{Social Utility}

The theme of social utility similarly appears in several different guises throughout these doctrines' evolution. At its heart, this rationale focuses on productive use of land. ${ }^{122}$ It is often expressed in the notion that land ought to have an owner. ${ }^{123}$ This is a somewhat puzzling assertion, because the question in all these cases is not whether the land will be unowned, but rather who will be the owner. ${ }^{124}$ Nonetheless, the underlying value asserted seems to be the social good of productive use of land by private landowners. This rationale appears in both early ${ }^{125}$ and recent ${ }^{126}$ cases.

A related notion that early commentators identified, but which fell out of favor, was that customary use, or something akin to prescription, justified the accretion doctrine. ${ }^{127}$ This Lockean notion of rewarding land

potential impact on the public interest. See Corpus Christi v. Davis, 622 S.W.2d 640, 644 (Tex. App. 1981) ("Application of the rule of avulsion to tidal lands would permit private ownership of land under the sea, would restrict the enjoyment of public beaches, would jeopardize the right of the public to navigate upon and to fish in the State's waters, and would render the location of seaward boundaries an exercise of pure guesswork.”); see also Walton County v. Stop the Beach Renourishment, Inc., 998 So. 2d 1102, 1113-14 (Fla. 2008) (quoting William BlaCKSTONE, 2 COMMENTARIES ON THE LAWS OF ENGLAND 261-62 (1743)) (describing common law doctrines as reflecting an attempt to balance public and private interests).

121. See, e.g., Walton County, 998 So. 2d at 1109, 1114-15 (discussing the balancing between public and private interests).

122. PowelL, supra note $6, \S 66.01[3] \mathrm{nn} .30 \& 32$. Powell also notes the flip side-the inefficiency of small isolated tracts of land surrounded by water. Id.; see also Aronow v. State, No. A120585, 2012 WL 4476642, at *2 (Minn. Ct. App. Oct. 1, 2012) (discussing the state's duty to put public land to productive use). See generally Swaim v. Stephens Prod. Co., 196 S.W.3d 5, 7, 11 (Ark. 2004) (examining the transfer of mineral rights and royalties of an unsevered mineral interest due to riverbank accretion).

123. See, e.g., Walton County, 998 So. 2d at 1118 (finding it is within the community's interest to ensure all land is owned).

124. See id. at 1105 (posing the issue of whether residents' land was taken, which required a determination of original ownership).

125. See Sax, Accretion, supra note 4, at 333 \& n.150 (discussing Lord Yarborough's case in which the House of Lords noted "occupation and improvement" as grounds for accretion, and stated that slowly accreted lands adjacent to a littoral landowner are of almost immediate use and value to the landowner, but "of no use to the King”). See generally Banks v. Ogden, 69 U.S. 57, 69 (1864) (expanding on the concept that land should not be left unowned).

126. See, e.g., Walton County, 998 So. 2d at 1114 (expanding on the public policy consideration that all lands should have an owner); Maunalua Bay Beach Ohana 28 v. State, 222 P.3d 441, 445 (Haw. Ct. App. 2009) (expanding on the public policy consideration that all lands should have an owner).

127. Sax, Accretion, supra note 4, at 319 (summarizing Hale's description of the Abbot of Peterborough's case). 
users has both fairness and utilitarian strains. ${ }^{128}$ This theme of rewarding use also appears in a form akin to archaic, almost mystical notions of property - that the land "becomes part and parcel of the upland estate" by virtue of the adjacent landowner's use. ${ }^{129}$

\section{Protection of Littoral Landowners' Right of Access to Water}

As Professor Sax points out, protection of the riparian right of access to water was not among the values explicitly considered in the early development of accretion and avulsion doctrines in Britain. ${ }^{130}$ However, it has become of primary importance in the United States, ${ }^{131}$ becoming arguably the single strongest rationale for both doctrines. ${ }^{132}$

\section{ERODING FOUNDATIONS: HOW SEA-LEVEL RISE UNDERMINES THE AMBULATORY BOUNDARIES FRAMEWORK}

The dynamic environment along our coasts today fundamentally differs from the environment assumed to exist at the water's edge when these doctrines were developing. Part II.A catalogs the ways in which sea-level rise creates a context that is distinct, in arguably relevant ways, from the context in which the ambulatory boundaries framework developed and has been applied until recently. It describes four key factual assumptions made in the cases from which the doctrine developed and in which they have recently been applied. These assumptions recognize that the environment is dynamic to some extent, but assume that the system operates within defined boundaries based on experience. ${ }^{133}$ It then describes how sea-level rise changes the factual context, such that these four assumptions are no longer true.

128. Id. at 333-34.

129. Id. at 330 (examining the rationale for the rule's method of disposing of land).

130. Id. at 347 .

131. Id. at 347-49 (describing the emergence of water access as the primary rationale in modern U.S. cases); see Bonelli Cattle v. Arizona, 414 U.S. 313, 326 (1973) (recognizing that the riparian quality of the land may be the land's most valuable feature). See generally TiFFANY, supra note 54, $\S 1219$ (stating that the rules are designed to protect a littoral or riparian owner's right of access to the water).

132. PoWELL, supra note 6 , § 66.01[3] n.36 (citing numerous cases and describing water access as "[t]he most persuasive and fundamental rationale" for accretion); see also State of Oregon v. Sause, 342 P.2d 803, 825 (Or. 1959) (quoting Hanson v. Thornton, 179 P. 494, 496 (Or. 1919) ("When we speak of riparian rights, we are not considering a mere shadowy privilege, but a substantial property right, the right of access to and a usufruct in the water.").

133. Professor Ruhl describes similar assumptions made by ecologists under the dynamic equilibrium model as exhibiting the flawed assumption of stationarity-fluctuation within an unchanging envelope of variability. Ruhl, Structural Transformation, supra note 13, at 1393-94. 
First, unlike the changes in littoral boundaries experienced historically, which were random and unpredictable, sea-level rise is predictable. ${ }^{134}$ Second, courts premised the ambulatory boundaries framework on the assumption that the change experienced by littoral landowners is equally likely to be a gain or a loss; in contrast, sea-level rise is "unidirectional,"135 as Joseph Sax aptly termed the change. ${ }^{136}$ Third, the changes experienced historically were episodic and geographically limited. Sea-level rise is ongoing and predicted to continue for hundreds of years, and it will have geographically pervasive effects and a broad social impact. ${ }^{137}$ Fourth, courts developed these doctrines to address all water bodies and assumed homogeneity of the processes of change affecting all water bodies. ${ }^{138}$ Sealevel rise only affects properties that are near to the coast. ${ }^{139}$ Part II.B elaborates on each of these archaic factual assumptions and the changes resulting from sea-level rise.

Part II.B then considers how these factual changes undermine the rationales that supported both the development and the current application of the ambulatory boundaries framework. It considers each of the five rationales for the ambulatory boundaries framework, evaluating how the changed facts affect the viability of these rationales. This raises the question of whether these doctrines, on their own terms, have continued application in the context of sea-level rise and, if so, how these changed facts should affect their application. ${ }^{140}$

134. Sax, Rising Sea Levels, supra note 5, at 645.

135. Id.

136. Id.

137. Id.

138. See infra Part II.A.4 (discussing common law’s failure to differentiate between different bodies of water).

139. Asbury H. Sallenger, Jr. et al., Hotspot of Accelerated Sea-Level Rise on the Atlantic Coast of North America, 2 NATURE Climate ChANGE 884, 884 (2012).

140. This analysis seems congruent with Professor Flatt's recommendation in the statutory realm, that in deciding how to apply or adapt a legal regime, one should identify "stress points in a changed future, and how legal and policy alterations can address those stress points while preserving the original purposes of the regime and considering both distributive justice and efficiency." Flatt, supra note 13 , at 287. In this setting, the archaic factual assumptions are the stress points, and the rationales underlying ambulatory boundaries framework are analogous to a statutory regime’s "original purposes." 


\section{A. Four Archaic Factual Assumptions}

\section{Predictability}

\section{a. The Assumption: Changes in Water Bodies Are Unpredictable}

The notion that the change in water bodies' profiles is random and unpredictable is almost part of the DNA of the ambulatory boundaries framework. Cases applying the ambulatory boundaries framework evince a fatalistic acceptance of the unpredictable vagaries of water bodies. ${ }^{141}$ References to the changes in the coastline that precipitated litigation in early cases suggest that the occurrence, direction, extent, and timing of these changes were random and unpredictable events. ${ }^{142}$ This factual predicate supports the fairness rationale for the accretion and the avulsion doctrines. ${ }^{143}$

\section{b. The Reality: Sea-level Rise Is Neither Random nor Totally Unpredictable}

Sea-level rise is a documented and ongoing process. ${ }^{144}$ It is not random, and it is becoming increasingly predictable. ${ }^{145}$ It is the subject of extensive scientific study. Technology has enabled scientists to estimate confidently the direction and likelihood of change over the coming decades,

141. See, e.g., Bonelli Cattle Co. v. Arizona, 414 U.S. 313, 326 (1973) ("Riparian land is at the mercy of the wanderings of the river.”); Severance v. Patterson, 370 S.W.3d 705, 708 (Tex. 2012) ("Oceanfront beaches change every day. Over time and sometimes rather suddenly, they shrink or grow, and the tide and vegetation lines may also shift. Beachfront property lines retract or extend as previously dry lands become submerged or submerged lands become dry.").

142. Cases involving avulsive events describe them as sudden and unusual. Severance, 370 S.W.3d at 708 passim (describing the sudden and dramatic changes in beachfront areas); Wood v. McAlpine, 118 P. 1060, 1064 (Kan. 1911) (holding that for an event to constitute avulsion, "the change ... must be ... sudden, and unusual....”). In cases involving accretion, courts emphasize the vagaries of changes that could make littoral owners either winners or losers. See supra Part I.D.2 (discussing the fairness rationale behind the ambulatory boundaries framework). While accretion cases often emphasize the bidirectionality of change in particular, these statements also suggest a general lack of predictability. The gain that a large accretion represents is often justified by the risk of an equally large erosion. See, e.g., United States v. 11993.32 Acres of Land, 116 F. Supp. 671, 678 (D.N.D. 1953) ("A rule of law cannot control the vagaries of a river. Hence, the general rule rests upon the equitable idea that a riparian owner should have the opportunity to gain by accretion since he is subject to the hazard of loss by erosion.”).

143. See supra Part I.D.2 (discussing the fairness rationale behind the ambulatory boundaries framework).

144. IPCC, Climate Change 2014 Synthesis RePort 2-4 (Paulina Aldunce et al. eds., 2015), http://www.ipcc.ch/pdf/assessment-report/ar5/syr/SYR_AR5_FINAL_full_wcover.pdf (noting observed changes in the climate system).

145. See id. at 10-16 (discussing past and present climate change observations and what future projections might be based on those observations). 
despite uncertainty about the pace of that anticipated change. ${ }^{146}$ Although the precise timing and extent of changes anticipated along the coast is uncertain, the fact that scientists can confidently predict the direction and likelihood of change has important ramifications for the rationales that justify the erosion and avulsion doctrines. ${ }^{147}$ Today, hurricanes, storms, and the attendant damaging storm surges are reasonably foreseeable for any coastal landowner with a structure close to the shoreline. ${ }^{148}$ The courts that developed and applied these doctrines clearly did not envision a generally predictable process that would continue for at least several hundred years, thereby giving landowners and the sovereign notice and opportunity to plan ahead.

\section{Directionality}

\section{a. The Assumption: Changes in Water Bodies Are Equally Likely to Move the Boundary in Either Direction}

The common law doctrines also envision that landowners may be winners or losers due to the vagaries of the tides on any given day. ${ }^{149}$ The land they were using might become submerged and no longer usable, or the sea might expose new usable land. Historically, litigants and courts seemed

146. E.g., DAVID ANTHOFf ET AL., Global and Regional Exposure to Large Rises in Sea-Level: A Sensitivity Analysis §§ 1, 2.1 (Tyndall Ctr. for Climate Change Research, Working Paper No. 96, 2006) (noting that "even if the climate is stabili[z]ed, sea levels continue to rise for many centuries due to the long timescales of the oceans and the large ice sheets"); Anny Cazenave \& William Llovel, Contemporary Sea Level Rise, 2 ANNUAl ReVIEW OF MARINE SCIENCE 145 (2010) (stating that tide gauge measurements showing significant sea-level rise have been available since the 20th century); John A. Church \& Neil J. White, Sea-Level Rise from the Late 19th to the Early 21st Century, 32 SuRV. GEOPHYSICS 585, 585-86 (2011) (stating that sea levels will continue to rise even if emissions are curbed and the atmosphere stabilized); IPCC, supra note 144, at 10-16 (discussing past and present climate change observations and what future projections might be based on those observations); SEA Level Rise Work Grp., Se. Fla. Reg'l Climate Change Compact., Unified Sea LeVel Rise PROJECTION FOR SOUTHEAST FLORIDA 1, 4, 7-8 (2015), http://www.southeastfloridaclimatecompact.or g/wp-content/uploads/2015/10/2015-Compact-Unified-Sea-Level-Rise-Projection.pdf (projecting the anticipated range of sea-level rise for the Southeast Florida region from 1992-2100).

147. This is explored in detail infra Part II.B.

148. The national media frequently cover not only extreme events such as Superstorm Sandy, but also the damaging effects of storm surge and tides exacerbated by sea-level rise. E.g., Lizette Alvarez \& Frances Robles, Intensified by Climate Change, "King Tides" Change Ways of Life in Florida, N.Y. TIMES (Nov. 17, 2016), http://www.nytimes.com/2016/11/18/us/intensified-by-climatechange-king-tides-change-ways-of-life-in-florida.html?emc=eta1\&_r=0 (examining the phenomena of "sunny day" flooding due to rising sea levels); Ian Urbina, Perils of Climate Change Could Swamp Coastal Real Estate, N.Y. Times (Nov. 24, 2016), http://www.nytimes.com/2016/11/24/science/globalwarming-coastal-real-estate.html?emc=eta1 (reporting that homebuyers are becoming increasingly wary of purchasing homes along the coast).

149. Sax, Accretion, supra note 4, at 320 . 
to assume that changes in the coast creating new land and submerging dry land were equally likely. ${ }^{150}$ This factual assumption of bidirectional change provides key support for the reciprocity rationale that, in turn, supports the accretion doctrine. ${ }^{151}$ The fact that one of the two directions in which change could occur exposed new dry land was also critical to both the social-utility rationale for accretion, ${ }^{152}$ and the rationale of protecting littoral landowners' access to water. ${ }^{153}$

\section{b. The Reality: Sea-level Rise is Unidirectional}

The factual assumption that coastal landowners have roughly equal chances of loss and gain is no longer justified in an era of sea-level rise. The scientific predictions regarding change along America's coast clarify that changes are no longer anticipated to occur with equal likelihood in both directions. ${ }^{154}$ Today, the dynamic along our coasts is (and will continue to be) predominantly erosion and inundation. ${ }^{155}$

150. See id. at 318 (quoting description from Abbot of Ramsey's case that "the marsh sometimes shrinks, through the influx of the sea, and at other times is enlarged by the flowing out of the sea ....”). Some cases involve a single geographic area that has recently experienced change in both directions. See, e.g., Siesta Properties v. Hart, 122 So. 2d 218, 219, 222-23 (Fla. Dist. Ct. App. 1960) (involving accretions that formed on a location where a barrier island had previously eroded).

151. See Bonelli Cattle Co. v. Arizona, 414 U.S. 313, 326 (1973) (describing a "compensation theory” that justifies awarding riparian landowner accretions); Banks v. Ogden, 69 U.S. 57, 67 (1864) (providing two different reasons coastal property owners should benefit from a receding sea); County of St. Clair v. Lovingston, 90 U.S. 46, 57 (1874) (reasoning that riparian property owners' gains through avulsion are a reciprocal consideration for their more frequent losses); Maunalua Bay Beach Ohana 28 v. State, 222 P.3d 441, 445 (Haw. Ct. App. 2009) (summarizing compensation or equity theory).

152. See Aronow v. State, No. A12-0585, 2012 WL 4476642, at *2 (Minn. Ct. App. Oct. 1, 2012) (discussing the state's duty to put public land to productive use); Swaim v. Stephens Prod. Co., 196 S.W.3d 5, 7, 11 (Ark. 2004) (examining the transfer of mineral rights and royalties of an unsevered mineral interest due to riverbank accretion); Walton County v. Stop the Beach Renourishment, Inc., 998 So. 2d 1102, 1118 (Fla. 2008) (finding it is within the community's interest to ensure all land is owned); Banks, 69 U.S. at 69 (expanding on the concept that land should not be left unowned); Maunalua Bay Beach Ohana 28, 222 P.3d at 445 (expanding on the public policy consideration that all lands should have an owner).

153. See Sax, Accretion, supra note 4, at 347-49 (describing the emergence of water access as the primary rationale in modern United States cases); PowELL, supra note 6, § 66.01[3] n.36 (describing water access as "[t]he most persuasive and fundamental rationale" for accretion).

154. E.g., Robert J. Nicholls \& Anny Cazenave, Sea-Level Rise and Its Impacts on Coastal Zones, 328 SCIENCE 1517, 1518 (2010) (finding that the immediate effect of SLR is submergence and increased flooding on coastland); SEA LEVEL RISE WORK GRP., supra note 146, at 10-11 (acknowledging the fact that an increase in loss of natural ecosystem services will cause coastal properties to lose more land to avulsion and erosion than have gains by accretion).

155. Of course, even in an era of sea-level rise, some coastal areas will experience accretion or reliction. However, the vast majority of littoral areas are facing inexorable and ongoing erosion or submersion. In addition, current erosion and attendant flooding on some areas of the coastline are more heavily influenced by inlet-management practices than by sea-level rise at present. Ruppert, supra note 
This changed reality has profound implications for our law and policy. It fundamentally alters the nature of the social problem posed by the dynamic coastline. Framing coastal change as sometimes presenting opportunities for social gains - in other words, presenting the possibility of winning or losing property in the coastal dynamic and the battle for title-is directly linked to the assumption of bidirectionality.

Because we are primarily a land-based species, there can only be meaningful social gains when the ocean recedes or land accretes, yielding more land for human endeavors. ${ }^{156}$ In contrast, submergence of land has almost always been experienced as a loss. ${ }^{157}$ Indeed, even a legal victory for a landowner whose land has been submerged awards that landowner nothing more than the right to reclaim the land from the ocean. ${ }^{158}$ In such cases, the changes to the coastline have not produced a social gain. On the contrary, the landowner has merely won the right to try to avoid a loss by undoing the social harm from the inundation.

The change from a win-lose dynamic to a lose-lose dynamic is significant. Instead of needing a legal framework that can both allocate gains and losses, we may need a framework designed to deal with a situation that will largely entail allocating losses, not gains.

31 , at $65,67,68$. Over time, however, sea-level rise represents a far greater threat and will overtake the effects of other human activities. See The Fla. OcEans \& Coastal Council, Climate Change And SEA-LEVEL RISE IN FLORIDA 11 (2010) https://www.flseagrant.org/wp-content/uploads/Climate_Chang e_and_Sea_Level_Rise.pdf. Moreover, increasing awareness of sea-level rise's impacts has motivated governments to improve inlet-management practices. In Florida, there is legislation requiring the Department of Environmental Protection to develop a statewide Beach Management Plan that includes inlet-management plans. FLA. STAT. § 161.161 (2010). Section 161.041(1)(b) requires that mitigation measures accompany authorization of inlet-management activities. Id. § 161.041(1)(b); see also Thomas P. Pierro, A Renewed Focus on Inlet Management: Committing to the Contributions of Dr. Dean and Senator Jones (Sept. 23, 2015), http://www.fsbpa.com/15AnnualConfPresentations/Pierro.pdf (demonstrating the need for further developments in inlet management in Florida).

156. Allocating title to additional submerged land to the sovereign may protect the sovereign's interest in owning the submerged lands all the way to the water's edge, but the incremental increase in the actual stock of submerged lands rarely has any tangible benefits for the sovereign or the public. Exceptional situations could include areas with oyster beds or valuable harborage. However, in most situations, the submergence of lands does not improve the sovereign's or public's position in a meaningful way. In most cases, a legal ruling awarding title to the sovereign merely prevents a lossloss of control over the crucial area at the water's edge.

157. Robert A. Morton, U.S. Geological Survey Ctr. for Coastal and Watershed Studies, Introduction: An Overview of Coastal Land Loss with Emphasis on the Southeastern United States, (2003), https://pubs.usgs.gov/of/2003/of03-337/intro.html.

158. See Walton County v. Stop the Beach Renourishment, 998 So. 2d 1102, 1116, 1117 (Fla. 2008) (explaining that landowners gain only the right to reclaim land lost to inundation up to the MHWL). 


\section{Frequency and Scope of Change}

\section{a. The Assumption: Changes in Water Bodies Are Episodic, Occasional, and of Limited Geographic Scope}

The common law doctrines developed to resolve the exceptional cases along an otherwise stable coastline. ${ }^{159}$ In most areas, courts only use the doctrines to address occasional, episodic changes caused by events such as hurricanes, ${ }^{160}$ by human activity, ${ }^{161}$ or in areas that are particularly susceptible to change. ${ }^{162}$ Historically, these cases were not only episodic; they were limited in geographic scope. ${ }^{163}$ Early courts and commentators frequently justified their decisions through the de minimis impact of applying these doctrines. ${ }^{164}$ As Sax explains, courts considered the impact of cases on the King's interest as de minimis even when the acreage involved was clearly significant. ${ }^{165}$ However, this characterization makes sense because the cumulative impact on the king's interest was limited. This was true because the changes experienced along the coastlines were limited in geographic scope, and thus unlikely to affect the public interest. ${ }^{166}$

159. See Sax, Accretion, supra note 4, at 312 (explaining that when the rule of accretion was applied to coastlines, transfer of title from sovereign to subject was considered exceptional).

160. See, e.g., Bryant v. Peppe, 238 So. 2d 836, 837 (Fla. 1970) (involving a controversy over a narrow strip of land that was a narrow strip of water before a hurricane struck); Siesta Properties v. Hart, 122 So. 2d 218, 220, 223-24 (Fla. Dist. Ct. App. 1960) (examining the effects of accretion on Florida coastal property rights following a hurricane).

161. See Bd. of Trs. of the Internal Improvement Tr. Fund v. Sand Key Assocs., Ltd., 512 So. 2d 934, 935 (Fla. 1987) (noting that a city-built jetty caused accretion). Inlet management and related human activities are a significant contributor to coastal erosion in many coastal areas, exacerbating the effects of sea-level rise, and in some areas dwarfing them. Ruppert, supra note 31, at 67-68.

162. See Robert E. Beck, The Wandering Missouri River: A Study in Accretion Law, 43 N.D. L. REV. 429, 436-37 (1967) (documenting several cases involving the Missouri River and its impact on riparian property rights); see also Siesta Properties, 122 So. 2d at 219, 220 (involving accretions that formed on a location where a barrier island had previously eroded).

163. Bryant, 238 So. 2d at 837; Siesta Properties, 122 So. 2d at 218, 219, 220.

164. See, e.g., Bd. of Trs. of Internal Improvement Tr. Fund v. Medeira Beach Nominee, Inc., 272 So. 2d 209, 212 (Fla. Dist. Ct. App. 1973) (identifying de minimis non curat lex as one of the reasons for the accretion doctrine); Walton County v. Stop the Beach Renourishment, Inc., 998 So. 2d 1102, 1113 (Fla. 2008) (listing de minimis impact as one of the four reasons for the accretion doctrine).

165. Sax, Accretion, supra note 4, at 313.

166. Id. at 329 . 


\section{b. The Reality: Sea-level Rise Is Ongoing and Geographically Pervasive}

Sea-level rise is an ongoing-not an episodic-phenomenon. ${ }^{167}$ Although periodic storms may accelerate the pace and extent of change in a given geographic area, ${ }^{168}$ there is adequate scientific evidence to conclude that sea-level rise is an ongoing and inexorable process. ${ }^{169}$ Changes in the coastline are also no longer the exception; they are now the norm, even if scientists cannot precisely predict the pace of the change. ${ }^{170}$ At the very least, courts should consider whether rules designed to handle an occasional, exceptional occurrence should apply when the exception becomes the rule.

Unlike the changes experienced in the past, sea-level rise is also geographically pervasive along our coasts. ${ }^{171}$ The anticipated changes along the nation's coasts threaten to impair the public's access to water and beaches. They also threaten ecosystem values throughout entire regions and states. ${ }^{172}$ Although sea-level rise will affect some areas less (because of topography or other factors), it is causing and will cause change along

167. Rusk, supra note 4, at 298.

168. See, e.g., John Hunter, A Simple Technique for Estimating an Allowance for Uncertain SeaLevel Rise, 113 Climatic ChANGe 239, 240 (2011) (suggesting that present evidence links rising sea levels to extreme weather events); IPCC, supra note 144, at 8 (finding that increasing occurrences of extreme weather events implies greater risks on a regional scale); Claudia Tebaldi et al., Modelling Sea Level Rise Impacts on Storm Surges Along US Coast, 7 ENVTL. RES. LETTERS, Jan.-March 2012, at 1, 1 (comparing the local characteristics of margins of continental shelves).

169. See, e.g., ANTHOFF, supra note 146, §§ 3.1, 4 (concluding that exposure of coastal areas to sea-level rise is significant and will likely grow substantially); Cazenave \& Llovel, supra note 146, at 146, 165 (finding that melting ice sheets also greatly affect sea-level rise); Church \& White, supra note 146, at 585 (acknowledging that sea-level rise will impact coastal populations); IPCC, supra note 144, at 2-4 (detailing scientific evidence in support of sea level rise); SEA LEVEL RISE WORK GRP., supra note 146, at 8-9 (providing examples of large-scale natural events that are accelerating the rate of sea levelrise and how those events are connected).

170. ANTHOFF, supra note 146, §§ 2.1, 3.1 (finding that, while projections and models are limited, sea-level rise is nevertheless plausible given long-time scales and commitment to sea-level rise); Cazenave \& Llovel, supra note 146, at 149-50 (finding great regional variability in the rates of sea-level rise changes); Church \& White, supra note 146, at 585-86 (explaining that global mean sea level is expected to continue rising despite uncertain projections); Nicholls \& Cazenave, supra note 154, at 1518 (highlighting the effect climate change has on coastal erosion).

171. See, e.g., Cazenave \& Llovel, supra note 146, at 150 (describing rates of variability in sealevel rise); Nicholls \& Cazenave, supra note 154, at 1518 (highlighting the effect climate change has on coastal erosion); Sallenger, supra note 139, at 884 (asserting sea-level rise has been relatively low on the North American coast); SEA LEVEL RISE WORK GRP., supra note 146, at 9 (highlighting several locations along the East Coast that are affected specifically because of their proximity to the Gulf Stream).

172. See, e.g., SE. Fla. Climate CompaCt CTYs., supra note 17, at 9 (examining the threat to coastal resources and ecosystems in Florida). 
significant portions of the coastline in many states, including Florida. ${ }^{173}$ This represents a different problem from the challenge of allocating risk in disputes that affect only a small number of coastal landowners and a limited stock of submerged lands held in public trust.

\section{Homogeneity of Water Bodies}

\section{a. The Assumption: Changes in Oceans, Lakes, Rivers, and Streams All Share the Same Characteristics}

The ambulatory boundaries framework treats rivers, lakes, and oceans similarly, with only subtle distinctions in the principles applied to them. ${ }^{174}$ To the extent that common law distinguishes among water bodies in applying accretion and avulsion, flowing rivers and streams constitute one category (riparian), while lakes and oceans constitute another (littoral). ${ }^{175}$ The fundamental failure to recognize significant differences among these water bodies and the processes that change their contours may contribute to the incoherence in the ambulatory boundaries framework that commentators have frequently noted. ${ }^{176}$ It may also explain the lack of coherence in the rationales for the doctrine, given that the values at stake in a lake, riverine, or coastal setting can be quite different. ${ }^{177}$ Notably, for example, cases involving lakes and oceans rarely involve state boundaries, while some of the highest profile cases applying the doctrine involve rivers along state boundaries. ${ }^{178}$

173. See Fla. DeP’t of EnVtL. Prot., supra note 30 (reporting $61 \%$ of Florida's beaches were designated as eroding as of August 2016); Baptiste, supra note 15 (noting the different types of effects Florida has faced and will face in the future because of sea-level rise); see also Cazenave \& Llovel, supra note 146, at 150 (showing the rising sea level on U.S. coasts).

174. See generally PowELL, supra note 6, § 66.01[2] n.11 (discussing traditional littoral and riparian values and the differential application of the doctrine of accretion); TIFFANY, supra note 54, $\S 995$ (treating "bank," "shore," "margin," and "edge” similarly insofar as setting the mean high- and low-water mark).

175. PowELL, supra note 6, § 66.01[2] 7.

176. See Sax, Accretion, supra note 4, at 321, 354 (providing different views that commentators have pieced together to form a coherent theory that meets their needs). For example, the explanation that is almost always used to explain the rationale for the rule governing avulsive events involves a river cutting through an oxbow or S-curve suddenly and unexpectedly. This scenario creates problems not presented in coastal settings.

177. PowelL, supra note 6, § 66.01[2] n.11 (citing Davis Oil Co. v. Citrus Land Co., 576 S.2d 495 (La. 1991)) (finding that riparian owners whose properties abut streams or rivers benefit from accretion, while riparian owners with properties abutting navigable waters, such as bays, do not).

178. See., e.g., Missouri v. Nebraska, 196 U.S. 23, 23, 24 (1904) (resolving a dispute about state boundaries along the Missouri River); Nebraska v. Iowa, 143 U.S. 359, 370 (1892) (discussing rivers in relation to state boundaries). 


\section{b. The Reality: Sea-level Rise Is a Distinctively Coastal Process}

Sea-level rise challenges the idea that a single doctrine should address changes in all riparian settings, particularly in the traditional doctrinal pairing of coastal and lakefront properties. Sea-level rise will affect estuaries at the mouths of rivers and perhaps some lakes that drain into coastal waters. ${ }^{179}$ However, in general, it will affect only the boundaries of properties in close proximity to the coast. ${ }^{180}$ This new reality supports reconsidering the continued application of existing common law doctrines or, at the least, tailoring their application in contexts where sea-level rise will be a factor.

The unified doctrine is not only unsuited to an era of sea-level rise; its development may also have been distorted by the different settings represented in case law. The vast majority of factual settings in cases applying avulsion are riverine. ${ }^{181}$ This raises the question of whether the doctrine makes sense in the coastal context. Moreover, several important riverine cases elaborating on the avulsion doctrine implicated state or other jurisdictional boundaries. ${ }^{182}$ This raises a number of considerations not implicated in cases involving the sudden submergence or erosion of coastal land. This article argues for careful consideration of whether the law of avulsion should apply in coastal settings generally, especially in light of the changes associated with sea-level rise.

179. The Great Lakes and their connection to the Atlantic Ocean through the St. Lawrence River may provide an example.

180. E.g., ANTHOFF, supra note 146, §§ 3.1, 3.2 .3 (finding that regions with "extensive[,] highly populated coastal lowlands” bear a disproportionate amount of damage from sea-level rise); Cazenave \& Llovel, supra note 146, at 150 (showing that sea-level rise is more pervasive along the southern coasts of the United States); Nicholls \& Cazenave, supra note 154, at 1518 (finding that sea levels are rising faster in subsiding coasts); Sallenger, supra note 139, at 884 (finding that the northeast hotspot (NEH) of accelerated sea-level rise is unique across North American coasts between Key West, Florida and St. John's, Newfoundland. Sea-level rate differences (SLRDs) in the NEH are three to four times larger than global SLRDs); SEA LEVEL RISE WORK GRP., supra note 146, at 9 (noting that coastal areas in particular have experienced an increase in flood frequency and will continue to do so at an accelerated rate).

181. See Sax, Accretion, supra note 4, at 311 n.24, 315, 351 nn.257 \& 259 (referencing cases that involve avulsion in rivers).

182. See, e.g., Missouri, 196 U.S. at 35 (noting additional cases that have involved the problem of avulsion in determining state boundary lines); Nebraska, 143 U.S. at 370 (involving a boundary dispute between Nebraska and Iowa resulting from changes in the course of the Missouri River). 


\section{B. How Archaic Factual Assumptions Undermine the Rationales for the Ambulatory Boundaries Framework}

Part II.A illustrates that the four factual assumptions on which the ambulatory boundaries framework is grounded are no longer true. This section considers how the changed factual reality directly affects the viability of the rationales that courts have offered to justify applying the doctrine. It highlights how the changed reality resulting from sea-level rise undermines or transforms the five rationales for applying the ambulatory boundaries framework.

\section{De Minimis Non Curat Lex and Archaic Assumptions About Predictability, Frequency, and Scope of Change}

The fact that sea-level rise is predictable, ongoing, and geographically pervasive erodes the factual foundation for the de minimis rationale. Commentators closely identified the de minimis rationale with the doctrines of accretion and erosion, although cases applying the avulsion doctrine have cited to it as well. ${ }^{183}$ Thus, the de minimis rationale seems to justify having a special set of rules for boundaries at the water's edge, rather than to justify applying the accretion or avulsion doctrines.

As noted above, ${ }^{184}$ the facts of the cases in which judges first articulated the de minimis rationale suggest that the focus was not on whether the acreage involved in a particular case was minimal or substantial, but whether the overall effect on the sovereign's interests was de minimis. ${ }^{185}$ The ongoing and geographically pervasive impacts of sealevel rise and the substantial costs they will impose eliminate the factual foundation for considering the changes occurring along our coasts as de minimis. ${ }^{186}$

Moreover, given that courts used the de minimis rationale to justify applying both the erosion and avulsion doctrines, the rationale cannot offer courts real guidance on how to resolve a case under the ambulatory boundaries framework. Thus, this rationale no longer seems relevant in the

183. Some of the early commentators on avulsion referenced by Sax posited that avulsion might be distinguished by the larger scale of the change experienced. Sax, Accretion, supra note 4, at 327 (describing Hale's standpoint). However the case law has ultimately not borne this out.

184. See supra Part I.D.1 (discussing the de minimis rationale).

185. Sax, Accretion, supra note 4, at 313.

186. See Walton County v. Stop the Beach Renourishment, Inc., 988 So. 2d 1102, 1118 (Fla. 2008) (concluding that critical erosion occurring on half of Florida's beaches is hardly de minimis). To the extent that a court seeks to apply the framework, perhaps this rationale might come into play in special settings where the impact could be viewed as de minimis. 
context of sea-level rise. The changed facts associated with sea-level rise undermine its utility and explanatory power.

2. Fairness and Archaic Assumptions About Predictability, Directionality, Frequency, Scope of Change, and Homogeneity of Waterfront Contexts

Courts using the fairness rationale to support the doctrine of accretion ground their decisions on the notion of reciprocity of risk-that coastal landowners risk both gains and losses in owning property close to the sea. ${ }^{187}$ Reciprocity justifies awarding coastal landowners land the sea exposed in order to offset the risk of loss from inundation. ${ }^{188}$ In cases of accretion, reciprocity of risk justifies awarding newly exposed land that belonged to the sovereign to coastal landowners. ${ }^{189}$ In addition, it similarly justifies awarding newly submerged land to the sovereign. This evokes a Rawlsian sort of fairness. Behind the veil of ignorance, courts operate under the premise that there is no information on who might gain or lose in the future. ${ }^{190}$ Because the assumptions of bidirectionality and unpredictability are no longer true, the notion of achieving fairness by allowing landowners to assume reciprocal risks is less convincing.

In an era of sea-level rise, there will be relatively fewer instances of newly exposed land. ${ }^{191}$ Thus, the fairness rationale argues even more strongly for awarding newly exposed land to landowners to compensate for losses that will become more frequent. Indeed, in a context of sea-level rise, an ambulatory boundary will frequently cause the landowner to bear the risk of loss with little prospect of reciprocal gain. However, coastal landowners are not alone in bearing these new risks of loss. ${ }^{192}$ All taxpayers will be sharing much of the cost that sea-level rise imposes, including: subsidized federal flood insurance for coastal landowners and landowners in flood-prone areas; disaster preparation and response costs that protect and assist coastal landowners disproportionately; and increased costs of

187. Sax, Accretion, supra note 4, at 308, 320-22.

188. Id.

189. Id. at 312 .

190. See Giancarlo Panagia, Tot Capita Tot Sententiae: An Extension or Misapplication of Rawlsian Justice, 110 PENN ST. L.R. 283, 285-86 (2005) (explaining that when acting behind the veil of ignorance, individuals must act in the interest of all because they do not know which group they will represent).

191. See supra note 180 and accompanying text (finding that the United States is likely to lose more of its coasts as the sea level rises).

192. Thomas Ruppert \& Carly Grimm, Drowning in Place: Local Government Costs and Liabilities for Flooding Due to Sea-Level Rise, 87 FLA. BAR J. 9, 31-32 (2013) (explaining how noncoastal landowners will still be affected by sea-level rise through mitigation efforts). 
maintaining coastal areas before permanent inundation. ${ }^{193}$ These costs inure to the benefit of coastal landowners disproportionately. ${ }^{194}$

The change in dynamic that sea-level rise creates-transforming a winlose equation to one that is largely lose-lose for all involved ${ }^{195}$ _affects the extent to which any single principle will achieve fairness. Coastal landowners' property interests will generally be adversely affected by an ambulatory boundary, while the public's interest will suffer under a fixed boundary. ${ }^{196}$ Thus, courts should arguably rethink how best to achieve fairness in an era of sea-level rise and whether the notion of "reciprocity of risk" has any continuing relevance.

The second way courts have invoked the fairness rationale distinguishes cases of rapid change from gradual change. ${ }^{197}$ Applying the avulsion doctrine to sudden change is often justified by expressed concern for the harsh surprises associated with sudden events, such as hurricanes. ${ }^{198}$ The idea is that landowners experience sudden, perceptible loss as a greater loss than a gradual, imperceptible one. Therefore, landowners should be protected from sudden losses and given the opportunity to reclaim their lands, but if and only if the lands are lost rapidly. ${ }^{199}$ However, the reason that a sudden loss evokes sympathy and a sense of unfairness is not just because a surprise causes an emotional shock. A sudden and unpredictable loss entails lack of warning and an inability to prepare for, mitigate, or avoid the loss. ${ }^{200}$ This underlies the notion that fairness supports the avulsion doctrine.

The predictable, unidirectional, ongoing, and pervasive qualities of sea-level rise, therefore, undermine this fairness justification for applying the avulsion doctrine even when the change to the coast occurs within a short timeframe. Sudden erosion wrought by storms is no longer a random, totally unpredictable, isolated, and anomalous event for coastal

193. Id.

194. Id. (highlighting that expenditures on coastal protections will force counties to incur great costs at the expense of other possible county projects).

195. See discussion supra Part II.A.2.b (expanding on the losses associated with inundation).

196. See McLaughlin, supra note 4, at 367-68 (describing the effects of sea-level rise in differing boundary regimes).

197. See Sax, Accretion, supra note 4, at 337 (examining the early rationale for the doctrine of avulsion).

198. See, e.g., Walton County v. Stop the Beach Renourishment, Inc., 998 So. 2d 1102, 1114 (Fla. 2008) (explaining that the hardship of removing title from an owner due to avulsive events is against the public interest).

199. See Sax, Accretion, supra note 4, at 308, 324 (arguing that the gradualness of the shift in boundary diminishes the loser's sense of loss); Rusk, supra note 4, at 299-300 (explaining that courts hesitate to shift boundary lines and burden private land after avulsive events).

200. See, e.g., Walton County, 998 So. 2d at 1114 (explaining the mitigating purpose of the doctrine of avulsion). 
landowners. ${ }^{201}$ Many landowners already have firsthand experience with the combined impact of sea-level rise and climate change on storm surges, and none can be unaware of the experiences along large portions of the United States' coastline in recent years. ${ }^{202}$ Landowners also have access to extensive information regarding likely future impacts. ${ }^{203}$ Those who decide to retain coastal property also have sufficient knowledge and opportunity to take steps to mitigate or insure against the associated risks. ${ }^{204}$ Many coastal landowners are building sea walls, elevating structures, and taking other measures to try to prolong the useful life of their properties, demonstrating their awareness of the threats. ${ }^{205}$

This reality undermines the rationale for applying the avulsion doctrine —allowing coastal landowners to reclaim submerged land because of the hardships occasioned by an unpredictable change. Thus, in an era of sealevel rise, factors-like the timing of the landowner's investments and the landowner's actual or imputed knowledge of ongoing erosion of a property — may be relevant to the analysis of fairness. Similarly, fairness could take account of the degree of hardship an ambulatory boundary would cause, including available statutory opportunities for the landowner to protect remaining structures. ${ }^{206}$

201. Peloso \& Caldwell, supra note 19, at 88.

202. E.g., Alvarez \& Robles, supra note 148 (chronicling efforts counties in Florida have made to prepare for rising sea levels); Urbina, supra note 148 (chronicling the increasing homeowner wariness about purchasing coastal properties).

203. There are free, publicly available mapping tools. See Office for Coastal Mgmt., NOAA's Sea Level Rise Viewer, NOAA, https://coast.noaa.gov/digitalcoast/tools/slr (last updated Nov. 3, 2017) (showing growing sea-level rise in an interactive map format); Surging Seas Risk Finder and Mapping Tools, Climate Central, http://sealevel.climatecentral.org/ (last visited Dec. 2, 2017) (providing interactive tools to see maps of areas that are below sea levels and experience flooding). There are also federal databases and tools that enable landowners to determine their flood exposure, see whether they are in a designated flood zone, and discover the meaning of that designation. See Office for Coastal Mgmt., NOAA Coastal Flood Exposure Map, NOAA, https://coast.noaa.gov/digitalcoast/tools/fl ood-exposure.html (last updated Oct. 19, 2017) (showing coastal flood exposure in an interactive map); FEMA Flood Map Service Center, FEMA, https://msc.fema.gov/portal/search (last visited Dec. 2, 2017) (providing tools to locate specific flood maps by address). In addition, there is a growing cadre of private consultants who will assess present and future flooding risk for coastal property owners or prospective purchasers. E.g., About Coastal Risk Consulting, COASTAL RISK CONSUlting, http://coastalriskconsulting.com/about (last visited Dec. 2, 2017).

204. See, e.g., Ruppert, supra note 31, at 90 (discussing certain permitting guidelines that give property owners notice of the risk of sea-level rise).

205. See id. at 97 (explaining that shore-armor permitting and beach nourishment efforts are attempts to insulate properties from sea-level rise).

206. Murr v. Wisconsin, 137 S. Ct. 1933, 1945 (2017) (reaffirming the relevance of preexisting conditions and landowner knowledge about the condition of the property and its likely uses in determining the appropriate denominator under the Takings Clause). Justice Kennedy noted that the physical characteristics of the property and the likelihood of regulation are relevant to the assessment of 
Thus, the situation for coastal landowners today is distinct from the paradigmatic case frequently invoked to justify applying the avulsion doctrine as a matter of fairness - the sympathetic case of the riverine property owner whose property becomes divided overnight by a river that suddenly and unpredictably cut through an oxbow or moved to a new channel. ${ }^{207}$ This has always been the classic case for applying the avulsion doctrine; the fairness rationale justifies providing the landowner opportunity to reclaim the property that is now across the river. ${ }^{208}$ Unlike the unlucky riverine landowner, coastal landowners today have notice and ability to decide whether they wish to continue to bear the risks associated with owning coastal property. ${ }^{209}$ Thus, the fairness justification offered to support the avulsion doctrine no longer makes sense. Although fairness may dictate that the avulsion doctrine should apply in a limited universe of cases, it will be an increasingly weak rationale as the effects of sea-level rise become more pronounced and widely experienced.

Moreover, the "surprise” narrative that justified the landowner's right to reclaim land after sudden changes is also no longer accurate. The new reality that sea-level rise poses means that making broad generalizations about the fairness of losing land to the ocean (as a result of sudden and perceptible changes, as opposed to a gradual change) is no longer possible.

the owner's reasonable investment-backed expectations, which in turn influence the denominator determination. Id. at 1945-46.

207. Compare Peloso \& Caldwell, supra note 19, at 88 (describing the situation of present-day coastal landowners), with Sax, Accretion, supra note 4, at 343-44 (describing the difficulties faced by a riparian owner on the banks of the Missouri River). See also Ruppert \& Grimm, supra note 192, at 3132 (noting the inevitable likelihood that maintaining essential public services in many coastal areas subject to regular inundation will become impossible or impracticable).

208. See, e.g., Sax, Accretion, supra note 4, at 351 (describing state of law as relegating avulsion to a minor role, except where there is a shift of a river into a new channel or in the case of a short-term change); see id. at 353 (recommending that the rule of accretion apply with a handful of exceptions, including a river that shifts to a new channel or cuts through an oxbow).

209. It is notable that property values have only recently begun to show signs of incorporating this risk. See Urbina, supra note 148 (noting that the real estate industry is slowly awakening to the need to incorporate risks of catastrophic damage from climate change into their pricing). In assessing the fairness of any given rule or outcome, it seems fair to consider that landowners have had an opportunity to exit the coastal property market and have not chosen to do so. While some may not have the resources to do so, given the large number of vacation and rental properties along much of Florida's coast, many clearly have the financial ability to do so but choose not to. In contrast, in locations where low-income and otherwise vulnerable populations live in coastal areas, fairness should remain a central, relevant consideration. 
3. Protection of the Sovereign/Public Interest and Archaic Assumptions About Predictability, Directionality, Frequency, and Scope of Change

As Professor Sax notes, early English common law valued protecting the sovereign's interest in previously submerged lands. ${ }^{210}$ Specifically, early British courts and commentators noted that privatizing large segments of coastal land might impair the king's strategic interest in controlling the coast. ${ }^{211}$ For this reason, courts took pains to clarify that interfering with sovereign interests could override other factors supporting a shift in title. ${ }^{212}$

This rationale of protecting the sovereign/public interest remains relevant in an era of sea-level rise. ${ }^{213}$ The sovereign continues to have a strong interest in the outcome of littoral boundary determinations and control over submerged lands held in trust for the public. ${ }^{214}$ However, the nature of the sovereign's interest has significantly changed.

Today, the sovereign's interest in land that becomes submerged because of erosion is less likely to be military or strategic, and more likely to reflect the contours of the public trust doctrine-emphasizing public use for navigation, bathing and fishing, and protecting public health, safety, and the environment. ${ }^{215}$ In Florida, the state constitution, statutes, and case law reflect the strength of the state's interest in preserving a foreshore that is accessible to the public and sandy beaches that are open for public use. ${ }^{216}$

The new reality of predictable, unidirectional, and geographically pervasive change amplifies this rationale's importance. The public interests and values associated with the foreshore are at considerable risk in an era of

210. See Sax, Accretion, supra note 4, at 312 (discussing the sovereign's right to rapidly exposed littoral land).

211. Id. at 325.

212. See id. at 312 (justifying transfer of title to private owners during accretion based on the de minimis rationale).

213. See Peloso \& Caldwell, supra note 19, at 84-85 (describing the public trust doctrine and its relevance to properties likely to be submerged due to sea-level rise).

214. See id. (offering an example of the state's interest in control over submerged lands).

215. See Bonelli Cattle Co. v. Arizona, 414 U.S. 313, 323 n.15 (1973) ("The extent of the State's interests should not be narrowly construed because it is denominated a navigational purpose.”).

216. See Fla Const. art. X, § 11 (providing that the state holds title in public trust all lands under navigable lands, including beaches below the MHWL); FLA. STAT. § 161.101 (2012) (recognizing beach erosion as a statewide problem and creating a state-initiated program of beach restoration and nourishment); City of Daytona Beach v. Tona-Rama, Inc., 294 So. 2d 73, 75 (Fla. 1974) ("No part of Florida is more exclusively hers, nor more properly utilized by her people than her beaches. And the right of the public of access to, and enjoyment of, Florida's oceans and beaches has long been recognized by this Court."); White v. Hughes, 190 So. 446, 449 (Fla. 1939) ("We love the oceans which surround our State. We ... enjoy bathing in their refreshing waters. The constant enjoyment of this privilege of thus using the ocean and its fore-shore for ages without dispute should prove sufficient to establish it as an American common law right....”). 
predictable, unidirectional, ongoing, and geographically pervasive erosion. ${ }^{217}$ The sovereign interest in and duty to protect the public's right to bathe, fish, navigate, and walk on the foreshore is at risk if there is no publicly owned foreshore or-in a more extreme case-if members of the public are separated from the water by private land (both dry and submerged). ${ }^{218}$ Occasional, episodic, and bidirectional changes of limited geographic scope do not pose a comparable threat to these interests. ${ }^{219}$

The state also has an interest in protecting other increasingly recognized ecological values of the area where dry land and sea meet. ${ }^{220}$ Dunes and other coastal features also provide natural protection against storms and flooding, not just for littoral property, but also for property and citizens living inland. ${ }^{221}$ If these naturally protective features are eroding, the state may have a strong interest in restoring them, especially when restoration is feasible and cost-effective. Thus, control over newly submerged lands may be critical to the state's ability to protect public health, safety, and the environment.

In eras when coastal change was occasional and limited, the impact on the sovereign's interest was correspondingly small. ${ }^{22}$ Thus, consideration of the sovereign's interest was, in some sense, pro forma in the early cases. ${ }^{223}$ Today, the ongoing and pervasive change along the coast intensifies the public interest and brings this consideration to the fore. ${ }^{224}$ This analysis suggests that the facts associated with sea-level rise intensify

217. Sax, Rising Sea Levels, supra note 5, at 645.

218. Sax, Accretion, supra note 4, at 356.

219. Id. at 325 (discussing how de minimis changes did not threaten the sovereign's interests).

220. In Florida, the area below the MHWL can include nesting habitat for sea turtles and critical habitat for other species. Blair Witherington et al., Sea Turtle Responses to Barriers on Their Nesting Beach, 401 J. EXPERIMENTAL MARINE BIOLOGY \& ECOLOGY 1, 1 (2011).

221. See generally OfFice of WetLAnds, OCEANs \& WATERSHEdS, U.S. ENVTL. Protection Agency, 842-R-15-002, GreEN INFrastruCture OpPORTUNITIES that ARISE DURING MUNICIPAL OPERATIONS, CASE STUDY: NORTH AND SOUTH RIVERS WATERSHED ASSOCIATION RAIN GARDENS (2015), https://www.epa.gov/sites/production/files/2015-09/documents/green_infrastructure_roadshow.p df (examining the impact of coastal-improvement projects on water quality); JEFFREY ODEFEY ET AL.,

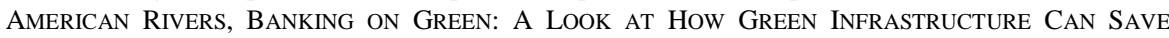
Municipalities Money and PROvide Economic Benefits Community-Wide 24 (2012), https://s3. amazonaws.com/american-rivers-website/wp-content/uploads/2017/03/06142720/banking-on-green-rep ort.pdf ("Naturally occurring 'green infrastructure' such as dune systems, wetlands (also known as living shorelines), and salt marshes can provide water storage and retention areas, mitigate tidal surges, reduce coastal erosion, and help to alleviate coastal flooding.”).

222. See Sax, Accretion, supra note 4, at 313 (discussing the original rationale behind the accretion doctrine).

223. See id. at 308, 309 (referring to views on historical deference to the sovereign Crown).

224. See Jen Van Allen, Coastal Access: “Interests in Tension,” IsLAnDS Inst. 2, 3 (Oct. 24, 2016), http://www.islandinstitute.org/working-waterfront/coastal-access-'interests-tension' (diving into current public access issues in Maine). 
the nature of the sovereign's interests. The pace and magnitude of the change, coupled with the ongoing, pervasive trend toward inundation clearly implicates a primary sovereign interest-protecting public safety. ${ }^{225}$ Unidirectional, predictable, ongoing, and pervasive change also poses a particular threat to the sovereign's interest in protecting public beach and water access and ecological systems.

Moreover, the sovereign's interests have weight because of not only its police power and duty to protect the public, but also the sovereign's interests as a landowner. ${ }^{226}$ Joseph Sax highlighted the implications of considering the sovereign's role not just as regulator, but also as trustee of sovereign submerged lands with a duty to protect the public's interest in these lands and navigation. ${ }^{227}$ This threefold strand of sovereign interests may offer the most robust grounds for courts and litigants seeking to adapt the doctrines to the realities of sea-level rise. This rationale provides a compelling reason to favor ambulatory boundaries that move as the shore erodes. This would better enable the sovereign to protect these various interests and fulfill its duties.

\section{Productive Use of Land/Social Utility and Archaic Assumptions About Directionality, Frequency, and Scope of Change}

A theme in the cases awarding private landowners newly accreted lands is their ability to make productive use of the newly created or exposed land. ${ }^{228}$ Commentators and courts have adverted to the value of having a clear owner who can use the land or of having an existing owner who currently makes productive use of the land. ${ }^{229}$ However, disputes over ownership of submerged lands weaken the relevance of this rationale. Cases of newly created or exposed land implicate the value of productive use of land-a value that the accretion doctrine advanced. ${ }^{230}$ Given that inundation of property is a fact that will predominate in an era of sea-level rise, the value of productive use and ownership of newly exposed or created land is not implicated in the same way.

Of course, in cases of erosion or submersion, landowners can still assert an interest in productive use of their land. Indeed, the avulsion

225. See also Peloso \& Caldwell, supra note 19, at 52, 56, 76-77 (noting how state interest in public safety might be met with legal obstacles).

226. See Sax, Rising Sea Levels, supra note 5, at 641-43.

227. Id. at 651 .

228. See Sax, Accretion, supra note 4, at 323-25, 333 (showing how productive use of land can correlate to awarded land via accretion).

229. Id.

230. Id. 
doctrine envisions that the landowner will somehow reclaim submerged lands, if reclamation is feasible within a reasonable time. ${ }^{231}$ This aligns with both the fairness rationale and the productive-use rationale. Presumably, a landowner would only invest in reclaiming lands if she was using or believed she could use these lands productively. However, when inundation occurs because of significant, ongoing, and geographically pervasive sealevel rise, the landowners' desire to reclaim and use inundated land is not innocuous. In many settings, reclamation may be socially undesirable and create significant externalities that other landowners and the public will bear. ${ }^{232}$ In some cases, it may put public health and safety at risk. ${ }^{233}$ Moreover, allowing landowners to use this land could interfere with navigation, water access, and other strongly protected public trust rights. ${ }^{234}$ Thus, the notion of productive use of land takes on a very different aspect in the context of sea-level rise.

As noted above, the rationale of promoting productive use of land by ensuring that all lands have an owner has not been prominent in cases of erosion. ${ }^{235}$ Courts typically invoked the rationale only in cases involving newly formed dry land that landowners could use productively. ${ }^{236}$ This rationale falls away when applied in the context of sea-level rise, as in other cases involving erosion.

Alternatively, one could argue that, while the underlying rationale remains relevant, the context of sea-level rise turns it on its head. Instead of providing a rationale for allowing littoral landowners to claim newly formed land, the considerable social value associated with public use of submerged lands provides an argument against allowing landowners to

231. Id. at 307-08 (providing historical context on why avulsion has different rules then accretion); see also Walton County v. Stop the Beach Renourishment, Inc., 998 So. 2d 1102, 1117 (Fla. 2008) (stating that the doctrine of avulsion recognizes owner's "right to reclaim the lost land within a reasonable time").

232. For example, in many settings, landowners' only feasible option is to construct a seawall to reclaim and protect submerged areas. Anne Schindler, Building a Great Wall—on Our Eastern Border, FIRSTCOAST NEWs (Oct. 20, 2016, 9:21 PM), http://www.firstcoastnews.com/news/local/building-agreat-wall-on-our-eastern-border/339378027. Seawalls frequently accelerate the pace of erosion on adjacent properties as well as any beach in front of them. Id.

233. Climate Change Impacts to U.S. Coasts Threaten Public Health, Safety and Economy, NOAA (Jan. 28, 2013), http://www.noaanews.noaa.gov/stories2013/20130125_coastalclimateimpacts.ht $\mathrm{ml}$ (looking at direct and indirect effects of climate change on coastal communities).

234. See Sax, Rising Sea Levels, supra note 5, at 644 (explaining that landowners making reclamation efforts have a duty to provide public access to the water).

235. See discussion supra Part II.B (considering how these factual changes undermine the rationales that supported the application of the ambulatory boundaries framework).

236. See Sax, Accretion, supra note 4, at 324-25 (explaining the justification for rewarding accreted land to existing owners). 
retain control after lands are submerged. ${ }^{237}$ Of course, one can also argue that the right accorded by the avulsion doctrine in cases of sudden and dramatic change preserves the landowner's ability to make productive use of the submerged land through reclamation. However, as sea level rises, reclamation will become practically impossible and, in some settings, dangerous. ${ }^{238}$ Thus, even if this rationale survives in the ambulatory boundaries framework, it offers less support for the avulsion doctrine than it does outside the sea-level rise context.

\section{Access to Water and Archaic Assumptions About Directionality of Change}

The final rationale offered to support the ambulatory boundaries framework is preserving littoral landowners' access to water. As noted above, this has become the predominant rationale of concern under United States case law. ${ }^{239}$ However, the concern that landowners may lose access to the water arises only in scenarios involving newly exposed or accreted lands placed in public ownership. ${ }^{240}$ In a context of unidirectional changewhere land primarily and persistently erodes - the landowner retains access to the water regardless of whether the boundary is static or dynamic. ${ }^{241}$ In other words, access to water is no longer an issue. Thus, the rationale that modern American courts rely on most prominently to justify applying the ambulatory boundaries framework is of questionable relevance in the context of sea-level rise.

237. Indeed, a rationale offered by early commentators to justify the doctrine of accretion-that the newly created land became in fact part of the land, so it made sense that it should become part of the tract at law-would argue for making newly submerged lands part of the waters rather than maintaining them as part of the land. See id. at 320 n.76 (describing commentary by Lord Hale).

238. See also Susumu Yasuda et al., Characteristics of Liquefaction in Tokyo Bay Area by the 2011 Great East Japan Earthquake, 52 SolLs \& Found. 793, 794 (2013) (describing the dangers of reclaimed land in Japan after the 2011 earthquake).

239. See supra Part II.B.5 (collecting cases and treatises that identify this as the most prevalent rationale under U.S. law).

240. See, e.g., Walton County v. Stop the Beach Renourishment, Inc., 988 So. 2d 1102, 110507, 1121 (Fla. 2008) (illustrating how beach restoration and renourishment may still lead to landowner claims of denial of access to water). In its decision, the Florida Supreme Court rejected the landowners' claim that beach renourishment pursuant to Florida's statutory scheme unconstitutionally took the landowner's right of access. Id.

241. See Sax, Accretion, supra note 4, at 346 (concluding that boundaries should follow a river's movement, no matter the form of the movement). 


\section{CleARING AWAy the Debris: Determining THE APPLICABLE LAW IN A POST-AMBULATORY BOUNDARIES LEGAL LANDSCAPE}

Part II described how five factual predicates for the development and application of ambulatory boundaries framework are absent or unfounded in an era of sea-level rise. Part II also described how these factual changes affect the viability of the rationales that supported applying the ambulatory boundaries framework. It illustrated how the coastal context resulting from sea-level rise fundamentally transforms the fairness and public interest rationales. It also detailed how the de minimis, social-utility, and access-towater rationales retain limited, if any, relevance. This section turns to the doctrinal implications of the changed factual reality of sea-level rise and outlines two possible paths for courts to take in resolving coastal boundary issues in this changed factual context.

The genius of common law is its ability to evolve as it encounters new situations. This section begins by addressing the general question of the circumstances under which common law judges can and should find that changed facts support changed outcomes. This discussion uses the term "doctrinally relevant" to describe facts that affect either the choice of the appropriate and applicable rule in a given case, or the outcome of applying a given rule. Both explicit, factual predicates for a given legal rule and facts that bear on the rationales for applying the relevant legal rule can be doctrinally relevant.

A change in a doctrinally relevant fact can affect a court's ruling on two different levels. At a superficial level, it can affect the court's decision on how to apply the rule, and potentially affect the outcome of the case. ${ }^{242}$ In other words, the same rule can apply in two cases, but the presence or absence of a particular fact may change the court's analysis, and may even determine a different outcome.

The second more fundamental level at which facts can affect a court's decision is when the presence or absence of a particular fact affects the selection of the applicable law. ${ }^{243}$ To give a very basic example, in criminal law, if the case involves unauthorized entry into a home and removal of an object, the offense is generally burglary. ${ }^{244}$ However, if the case involves authorized entry and removal of an object, the offense is typically theft, but

242. See, e.g., Garratt v. Dailey, 279 P.2d 1091, 1093-94 (Wash. 1955) (holding that absence of a finding of intent to cause harm supports a conclusion that no battery occurred).

243. See Lucy v. Zehmer, 84 S.E.2d 516, 520 (Va. 1954) (finding that circumstances of the case did not warrant application of the rule governing enforcement of a contract made while intoxicated, but fell instead under the general rule governing contracts).

244. 18 PA. CONS. STAT. § 3502 (2017) (defining burglary). 
not burglary. ${ }^{245}$ The presence or absence of unauthorized entry determines the applicable rule. This occurs when facts are elements of a given legal claim. It can also occur even where the fact is not an identified predicate or element of a claim. ${ }^{246}$

Therefore, if a court determines that the effects of sea-level rise constitute doctrinally relevant facts, it must subsequently determine how the facts affect the analysis. The court can: (a) factor the effects of sea-level rise into its analysis and potentially reach a different result under the ambulatory boundaries framework; or (b) recognize that the effects of sealevel rise warrant applying different legal principles from the traditional ambulatory boundaries framework. After a discussion of how courts determine which facts have doctrinal relevance in Part III.A, Parts III.B and III.C explore these two approaches. Part III.B considers a first option: the conservative approach. Under this approach, courts will apply the ambulatory boundaries framework, but explicitly recognize that the effects of sea-level rise necessitate changes in how the doctrines are applied. This will align the ambulatory boundaries framework with the rationales that support its application.

Part III.C considers a second, more comprehensive approach. A court could conclude that the common law framework is, by its terms, inapplicable in this new setting. It could then apply the remaining substantive body of law that governs property boundaries and ownership, public trust, and submerged lands without the overlay of the ambulatory boundaries framework. Part III.C then examines how these bodies of law, composed of constitutional, statutory, and common laws, might apply to coastal properties in the absence of the ambulatory boundaries framework.

Finally, Part III.D anticipates some of the arguments against adapting or supplanting the traditional framework, including the argument that the latter approach constitutes a change in settled law that denies property owners due process, or constitutes a “judicial taking” without just compensation.

\section{A. The Relevance of Changed Facts: What's a Court to Do?}

A basic premise of our common law tradition is that judges decide cases by applying the principle of stare decisis. They employ the techniques of reasoning-by-analogy and distinguishing cases to determine whether a

245. Id. § 3921 (defining theft).

246. See M.B.W. Sinclair, The Semantics of Common Law Predicates, 61 IND. L. ReV. 373, 378-80 (1986) (explaining what predicates are and how they apply in a legal context). 
prior decision is binding precedent to a subsequent case. ${ }^{247}$ This requires identifying "doctrinally relevant" facts, such that the presence or absence of the fact affects the choice of rule or the outcome of the case when the court applies the rule. ${ }^{248}$ Thus, judges confronted with two cases-only one of which involves a doctrinally relevant fact-may arrive at different decisions either because (1) different rules govern the two cases; or (2) because the same rule, properly applied to the facts, produces divergent results.

Courts may find two different categories of facts doctrinally relevant. The first category is composed of facts that constitute elements of a particular rule. The second category is composed of facts so critical to applying the rule that they can affect the choice of rule or outcome, even though they are not elements of the rule. In the first category, the fact is already recognized as a requisite for applying the prior decision or rule. ${ }^{249}$ In the second category, the fact's relationship to the rationale underlying the rule determines its significance to the outcome. ${ }^{250}$ The argument elaborated in more detail below is that, when confronted with the changed reality of sea-level rise, courts applying the ambulatory boundaries framework should find that the effects of sea-level rise are facts that fall into the second category and are therefore doctrinally relevant.

Under stare decisis, courts are bound to apply the applicable law similarly to cases involving similar facts. ${ }^{251}$ However, where doctrinally relevant facts differ in two cases, courts may decide: (1) that the same legal principle or rule applies, but factual distinctions warrant a different outcome; or (2) that a different legal principle or rule applies to the two cases. ${ }^{252}$ In other words, courts employ the techniques of reasoning-byanalogy and distinguishing cases at two distinct levels of application: application of the rule to the facts and selection of the relevant rule. ${ }^{253}$

In the first situation, a court distinguishes two cases because it identified a material factual difference from a prior decision that affects

247. See, e.g., Harry W. Jones, Our Uncommon Common Law, 42 TenN. L. REV. 443, 457 (1975) (explaining the history of precedent).

248. Id. at 356 (commenting on the different ways that a court may decide a case, despite sometimes having similar facts).

249. E.g., Garratt v. Dailey, 279 P.2d 1091, 1093-94 (Wash. 1955) (stating that intent to cause harm is a requirement for battery, no matter the circumstances or character of that intent).

250. E.g., Lucy v. Zehmer, 84 S.E.2d 516, 520 (Va. 1954) (finding that the evidence did not support the conclusion that the defendant was sufficiently intoxicated, to warrant application of the rule invalidating contracts made while unable to comprehend the nature and consequences of the instrument executed).

251. Jones, supra note 247, at 456.

252. Id. at $456-57$.

253. Id. at 458 . 
how a particular principle or rule applies to the case before it. ${ }^{254}$ In such a case, the court has already identified a legal doctrine or principle that applies to both cases. Thus, the factual difference does not affect that determination. However, the court may conclude that material factual differences warrant a different analysis and outcome. ${ }^{255}$ For example, consider a case in which one landowner (P) claims that a boundary has been modified by estoppel. Assume that the neighboring landowner (D) expressly permitted $\mathrm{P}$ to use land within the actual boundaries of D's property up to a fence D built that was several feet inside D's boundary. Assume further that $\mathrm{P}$ used the land and subsequently built her own fence abutting D's fence. If D now seeks to preclude P from using the area within D's boundaries, P may claim that a new boundary at the fence line has been established by estoppel.

A court might decide that-although a plaintiff proves the strict elements of boundary-by-estoppe ${ }^{256}$-material factual differences from prior cases warrant distinguishing the situation. For example, the evidence might show that $\mathrm{D}$ merely tried to be a good neighbor, reasonably believed that $\mathrm{P}$ knew that $\mathrm{D}$ was merely granting a permissive use of D's land, and had no warning that $\mathrm{P}$ would build a fence. In such a case, a court might decide that boundary-by-estoppel should not apply because the primary rationale underlying estoppel is preventing wrongful conduct. Therefore, innocent, good faith acts should not qualify. ${ }^{257}$ Thus, the court might conclude that, based on these facts and notwithstanding existing law, no estoppel should be found. ${ }^{258}$

Courts engage in a somewhat similar but distinct process when they decide that a particular principle or rule applied in a prior case should not be applied in a subsequent case because of factual differences between the two cases. ${ }^{259}$ This arises when a case arguably could be decided under

254. Id

255. Id.

256. The elements for proving boundary-by-estoppel in a majority of jurisdictions are an express or implied (by conduct) misrepresentation of the boundary by the party to be estopped, and reliance on the misrepresentation by another party who lacks notice of the truth. Notice of the truth is also required for the party to be estopped, but such notice can be actual or imputed. PowELL, supra note 6 , § 68.04[5][a].

257. See, e.g., Bryant v. Peppe, 238 So. 2d 836, 839 (Fla. 1970) (reiterating that equitable estoppel pleas are not sufficient when based on mistaken actions).

258. See PowELL, supra note $6, \S 68.04$ [2] (explaining how the rigorous factual requirements negate potential estoppel claims); see, e.g., Benz v. St. Paul, 93 N.W. 1038, 1040 (Minn. 1903) (declining to find boundary-by-estoppel where landowner to be estopped did not have actual knowledge of where boundary was in relation to the house plaintiff built).

259. In their book, Reason in Law, Lief Carter and Thomas Burke term this "fact freedom." LIEF H. CARTer \& Thomas F. Burke, ReAson In LAW 28 (8th ed. 2010) ("We call judicial freedom to 
either of two legal principles or rules. ${ }^{260}$ The court may find that relevant factual differences between a prior and a subsequent case affect the court's decision as to which legal framework or principle should apply. ${ }^{261}$ For example, consider a case that can arguably be resolved under two different property law principles, such as boundary-by-acquiescence and boundaryby-estoppel. ${ }^{262}$ In this case, assume that our landowner (P) claims that the boundary with a neighbor's (D's) property has been modified by acquiescence. Again, assume that $\mathrm{P}$ used land up to a fence that ran several feet inside D's boundary. P might cite prior cases with similar facts (e.g., a case where the actual owner acquiesced to P's use of property up to an existing fence that was not on the boundary) to support her claim. However, a court could decide that the boundary-by-acquiescence doctrine does not control the case because the length of time does not justify invoking the underlying rationale of favoring diligent landowners and disfavoring landowners who sleep on their rights. ${ }^{263}$ Instead, the court might find that the boundary-by-estoppel doctrine controls the case. ${ }^{264}$ The presence or absence of a particular fact-in the example, a sufficient length of timedetermines that different rules apply in two factually similar cases.

By analogy, the factual differences between current cases and earlier cases resulting from sea-level rise could lead a court to conclude either: (1) that the factual context of sea-level rise is doctrinally relevant and must be considered in applying the ambulatory boundaries framework; or (2) that the factual context of sea-level rise so directly and substantially undermines the rationales for applying the ambulatory boundaries framework that they should no longer apply. Part III.B illustrates the first path: a court applying the ambulatory boundaries framework, but taking account of the doctrinally relevant factual differences. Part III.C describes the second path: a court determining that, in light of the factual differences, the ambulatory boundaries framework does not apply in the context of sea-level rise.

\footnotetext{
choose the governing precedent by selectively sifting the facts of prior cases and weighing their relative significance fact freedom.”).

260. Id. at 27.

261. Id. at 29.

262. Id. at 43-47.

263. See PowelL, supra note 6, § 68.05[1][c] (explaining how firm time periods and other technicalities may limit certain property claims); see Wells v. Williamson, 794 P.2d 626, 629 (Idaho 1990) (outlining the rationales underlying boundary-by-acquiescence).

264. See PowelL, supra note 6, § 68.04[4] \& [5][a] (stating practical location may establish boundary-by-estoppel).
} 


\section{B. Option One: Apply the Ambulatory Boundaries Framework with Explicit Consideration of the Changed Factual Context}

Because the changes presented by sea-level rise undermine and transform the rationales for the ambulatory boundaries framework, courts should, at least, take account of material facts in their analysis when applying the law to the facts before them. In doing so, courts will find that, in many cases, some of the rationales for applying the doctrine have become irrelevant, such as the de minimis rationale, preservation of access to water, and ensuring productive use of land. Other rationales, such as fairness and protection of the public interest, remain relevant, but the changed facts may turn the rationales on their heads, justifying completely different results.

Confronted with this challenge, courts should acknowledge that the facts presented in a context of sea-level rise are significantly different from those that existed historically. In appropriate cases, courts could find that these facts are different in ways that are materially relevant to applying the ambulatory boundaries framework. These changed facts undermine key assumptions and rationales for applying the specific doctrines. This section offers a conservative approach for courts to account for these factual changes. This approach focuses on the close connection between the historic factual predicates and the rationales that support the doctrines. ${ }^{265}$

Under this approach, a court explicitly acknowledges that the changed context presented by sea-level rise requires rethinking the rationales that support applying the ambulatory boundaries framework. ${ }^{266}$ Therefore, in applying the doctrines, the court considers how the changed facts affect the underlying rationales. ${ }^{267}$ Rationales that are no longer relevant in the context of sea-level rise should not weigh in a court's analysis. Rationales that are still logically relevant may require courts to reconsider what result will achieve the purpose of the doctrines, potentially affecting the analysis and the outcome in an era of sea-level rise. If applying the doctrine directly conflicts with the rationales that support the doctrine, courts should reconsider the doctrine's application to the facts of a particular case.

265. See Flatt, supra note 13, at 290-91 (enumerating a similar approach that seeks to adapt statutes while maintaining a focus on the underlying purposes of the law).

266. See Christie, supra note 3, at 46, 47-48 (describing effects of accretion, avulsion and erosion on littoral rights); Peloso \& Caldwell, supra note 19, at 67-68 (explaining doctrines of accretion, erosion and avulsion).

267. See Christie, supra note 3, at 46-48 (describing the effects of accretion, avulsion, and erosion on littoral rights); Peloso \& Caldwell, supra note 19, at 67-68 (explaining doctrines of accretion, erosion, and avulsion). 
The analysis in Part II.B demonstrates that the de minimis, socialutility, and access-to-water rationales are no longer viable in the context of sea-level rise. Arguably, courts should no longer recite these by rote or rely on them to justify application of the ambulatory boundaries framework. Focusing on the difficult, but important questions of fairness, and the broad dimensions of public interest in coastal boundaries could produce a sounder application of the ambulatory boundaries framework-one that better achieves the doctrines' purposes.

In some cases, rationales that are invoked by rote as supporting the avulsion doctrine no longer support the same outcome. ${ }^{268}$ Moreover, in some cases, fairness may dictate overriding application of the accretion doctrine. ${ }^{269}$ By undertaking a meaningful and nuanced analysis of the values that remain relevant, courts ensure that the doctrines serve their purpose, rather than applying them mechanically and in ways that ignore reality.

This proposed path represents a conservative approach to the challenge that sea-level rise presents for the ambulatory boundaries framework, but it could nevertheless dramatically affect outcomes. Rather than being bound by the tyranny of the fast-slow distinction-with its significant information costs, lack of predictability, seemingly arbitrary results, and doctrinal incoherence-courts consider the values that the doctrines will serve: fairness and protecting the public interest. Admittedly, these rationales require courts to better define what achieves fairness and protects the public interest in this new era, but courts face similar challenges in applying many legal doctrines. ${ }^{270}$ Through this method, courts will focus on protecting meaningful social values, rather than determining whether and how much of the erosion in a given case was caused by events observable by a person unaided by technology, with all the absurd subsidiary questions that inquiry entails. ${ }^{271}$

\section{Option Two: Set Aside the Ambulatory Boundaries Framework}

Part III.B offers the conservative approach that a court might take when confronted with the challenge of applying the ambulatory boundaries

268. See Sax, Accretion, supra note 4, at 351-53 (describing cases where courts arbitrarily followed doctrinal precedent and engaged in wasteful disputation).

269. Id.

270. E.g., Peter H. Schuck, The Transformation of Immigration Law, 84 ColuM. L. ReV. 1, 50 (1984) (describing how courts have moved away from traditional doctrines of autonomy and selfdetermination in contract law to fairness and social justice).

271. See Sax, Accretion, supra note 4, at 352-55 (proposing courts change their analysis of property interests to include public use and environmental concerns). 
framework in the context of sea-level rise. This section outlines an alternative and comprehensive path: reconsidering whether the ambulatory boundaries framework is the proper law to apply in this context. If a court concludes that the ambulatory boundaries framework does not apply to cases of coastal erosion in an era of sea-level rise, the most logical and arguably correct outcome is not to apply the framework. It is unquestionably the province of courts to determine the applicable law. ${ }^{272}$ Moreover, cases in which parties argue for the application of competing legal frameworks to a single set of facts are common. Courts routinely resolve these questions. ${ }^{273}$ This part outlines what that approach might look like.

If one removes the erosion-avulsion overlay from the picture, several important bodies of law remain for courts to apply. ${ }^{274}$ First, under real property law, there are doctrines that determine boundaries to property. ${ }^{275}$ As a general matter, the land descriptions in a deed typically establish boundaries. ${ }^{276}$ In general, those boundaries do not change absent voluntary conveyance or the exercise of eminent domain. ${ }^{277}$ This seems to suggest applying a rigid rule that permanently fixes boundaries without regard to the movement of the sea. However, common law has always included numerous exceptions to this basic principle, including the doctrines of adverse possession, post-conveyance agreement, estoppel, and acquiescence. ${ }^{278}$ These exceptions serve rationales similar to those incorporated in the ambulatory boundaries framework-including fairness, promoting the productive use of land, and efficiency. ${ }^{279}$ Similarly, although

272. Samuel Issacharoff, Concepts and Insights Series: Civil Procedure 93, 96 (3d ed., Thomas Reuters 2012).

273. See supra Part III.A (examining the use of precedent and stare decisis).

274. As noted earlier, these doctrines function as an overlay on background legal principles that would otherwise require a transfer of property in order to change ownership of the disputed area. See Sax, supra note 4, at 311-12 (discussing alternative bodies of law).

275. POWELL, supra note 6, § 68.02 .

276. See TIFFANY, supra note 54, § 990 ("The language of the conveyance by which the land is sought to be identified is usually referred to as the 'description.'”). In Florida, there is also a statutory overlay on the common law specifying that the seaward boundary of littoral property is the MHWL. FLA. STAT. § 177.28 (2016). Subsection (2) of this provision states: "No provision of this part shall be deemed to modify the common law of this state with respect to the legal effects of accretion, reliction, erosion, or avulsion.” Id. $\S 177.28(2)$. This subsection would simply have no relevance if erosion and avulsion did not apply to a given context.

277. POWELL, supra note 6, § 68.02 .

278. Id. § 68.05[1][d].

279. Id. § 91.01[4] (explaining that adverse possession serves the policy of maintaining what has become the status quo when the costs of wrestling the land may be too great); id. § 82.01[3] (explaining that recording acts are aimed at protecting purchasers who had no prior notice of ownership over the property and make property law self-executing and efficient); id.§§ 68.059[c], [d] (explaining that the doctrine of recognition and acquisition aims to fulfill equitable policies); see also Sax, 
doctrines and statutes define the requirements for a valid voluntary transfer of land, numerous exceptions that shift ownership without a valid transfer, including estoppel, exist in a variety of situations. ${ }^{280}$ Moreover, the protections afforded bona fide purchasers under common law, as codified in state recording statutes, ${ }^{281}$ can override these rules and invalidate voluntary transfers, or give effect to otherwise invalid transfers.

Thus, the law that defines boundaries and generally requires a voluntary transfer or exercise of eminent domain to transfer title to land is the first point of reference for courts seeking to determine the effect of a changed coastline on property rights. ${ }^{282}$ Ordinarily, absent circumstances that require applying an exception, the existing law retains the boundaries of a littoral property, notwithstanding the movement of the MHWL. However, determining the location of a boundary generally begins with the description of the property in the deed. ${ }^{283}$

In Florida, the seaward boundary of littoral property is the MHWL. ${ }^{284}$ Grants from the state that are not exceptional grants of sovereign submerged lands cannot extend seaward of that line. ${ }^{285}$ Boundaries described with reference to the MHWL create a presumption that the parties intended the boundary to be ambulatory. ${ }^{286}$ Of course, there may be cases in which a specific surveyed description of the MHWL at the time of the grant is included in a deed. ${ }^{287}$ In such cases, parties can argue that they intended the boundary to remain fixed at that location. However, even when the parties describe the specific geographic location of the water's edge as the boundary, courts frequently find that the parties intended to use the water's edge as the boundary, departing from the rule of strict construction. ${ }^{288}$ Thus, beginning from the property description, a court may find that the parties generally intended to use the ambulatory water's edge as the boundary, instead of a fixed surveyed location. This argues in favor of a rule allowing

Accretion, supra note 4, at 323-24, 340 (explaining that ambulatory borders promote land efficiency and fairness).

280. See TIFFANY, supra note 54, § 1230 (explaining estoppel by deed); id. § 966 nn.4-5 (explaining estoppel based on part performance or reliance).

281. POWELL, supra note 6, § 82.01[3].

282. TIFFANY, supra note 54 , § 1220 .

283. Id.

284. FLA. STAT. § 177.28(1) (1974).

285. See id. (providing that no waiver of state ownership over submerged lands is valid).

286. See id. § 253.12(9) (providing that state grant of tidally influenced lands are in the public interest, and that the boundary between state and private land will be ambulatory).

287. See, e.g., Walton County v. Stop the Beach Renourishment, Inc., 998 So. 2d 1102 (Fla. 2008) (highlighting how rising sea levels effectively change deeded land in coastal property rights).

288. POWELL, supra note 6, § 66.03[1]. 
the boundary to move, in order to respect the construction of the property description in the deed or grant.

Because littoral property bounds on sovereign submerged lands, its boundaries raise an additional question. How does or should the law treat additions to the stock of submerged lands in the absence of the doctrines of erosion and avulsion? The body of law governing these lands held in the public trust is rich and extensive. ${ }^{289}$ In Florida, both the state constitution and common law clarify the special status accorded to sovereign submerged lands. ${ }^{290}$ The strength and importance of the public's claim on these lands, the limited right of the sovereign to convey them, and the importance of the right of navigability and recreation in the ocean all suggest the need for great caution in allowing newly submerged lands to pass into private ownership.

Even the doctrine of avulsion, as it currently operates, gives landowners a very qualified right in cases of erosion: the right to reclaim newly submerged land. ${ }^{291}$ Thus, to the extent that the law affords a littoral landowner a right to newly submerged land under the avulsion doctrine, that right is limited to reclaiming the submerged land within a reasonable time. ${ }^{292}$ The very limited nature of this right to reclaim is noteworthy. Unlike in cases of accretion, the avulsion doctrine does not award title to the littoral landowner; it merely provides a right to reclaim. ${ }^{293}$ This protects the strong public trust interest in the submerged lands. The strength of this interest is also evinced in the Florida Constitution, which limits the sovereign's ability to alienate sovereign submerged lands absent a finding that such alienation is in the public interest. ${ }^{294}$ Both the strong constitutional protection accorded sovereign submerged lands in Florida, and the weak protection afforded the previous owner of newly submerged lands under the ambulatory boundaries framework, point to allowing the boundary to move landward as sea level rises.

289. See Walton County, 998 So. 2d at 1109-14 (discussing detailed history of public versus private property issues).

290. See supra Part.I.A. (discussing the status of submerged lands under Florida common law and Florida statutes).

291. TIFFANY, supra note $54, \S 666$.

292. See Walton County, 998 So. 2d at 1117 (“[W]hen an avulsive event leads to the loss of land, the doctrine of avulsion recognizes the affected property owner's right to reclaim the lost land within a reasonable time.”).

293. In New York, the right to reclaim is stronger. See New York v. Realty Assocs., 176 N.E. 171, 172 (N.Y. 1931) (accepting the doctrine that sudden submergence does not divest the private owner of title pending reclamation; title remains in the riparian owner).

294. FLA. CONST. art. X, § 11 ("Sale of [sovereign submerged] lands may be authorized ... only when in the public interest. Private use of [these] lands may be authorized by law, but only when not contrary to the public interest."). 
Moreover, allowing landowners to exclude the public from expanses of the wet sand area, and eventually even areas below the mean low-water mark, would inevitably interfere with public rights to navigate, bathe, fish, and otherwise enjoy the waters of the state. The primacy and importance of these rights is well established. ${ }^{295}$ If these public trust rights do not sufficiently justify ensuring that submerged lands remain in public ownership, the state's economic dependence on beach tourism adds to the policy reasons for protecting public access to the beaches and waters of the state. $^{296}$

Practical considerations also point to this direction. A rule that leaves the property boundary fixed, even as the boundary moves farther from shore, would create innumerable practical problems. Walton County, located in Florida's panhandle region, has already experienced intense conflicts because littoral landowners installed fences to enclose the beach above what they believed to be the MHWL, in efforts to exclude the public from the dry sand beach. ${ }^{297}$ Many beachfront owners posted signs intended to keep the public off the dry sand beach, without a clear understanding that the public may have already acquired rights to use the dry sand beach under the doctrine of customary use. ${ }^{298}$ The resulting conflict led the county commission to develop an ordinance that sought to mediate the conflict between the public's rights and the landowner's interests. ${ }^{299}$

A rule that encourages landowners to continue to think of submerged lands as their private property would extend this type of conflict from the dry sand into the waters themselves. In this setting, the potential for landowner interference with navigation and beachgoers' access to the water would intensify the challenges local or state governments face in developing rules to regulate landowner conduct and protect the public interest. According landowners title to submerged lands would also

295. See Doremus, supra note 3, at 1106 (describing these rights as an easement to the public from the state).

296. See Christie, supra note 3, at 38 (listing the benefits accrued from beach restoration).

297. Walton Update, supra note 34; Dotty Nist, Citizens Ask Commissioners to Ensure Public Access and Use of the Beach, THE DEFUNIAK HERALD (Mar 28, 2016), https://defuniakherald.com/ uncategorized/citizens-ask-commissioners-to-ensure-public-access-and-use-of-the-beach/.

298. Wheeler, Walton Comm'n, supra note 28.

299. Id. It achieves this through a zoning strategy that creates a 15 -foot buffer zone measured seaward from the toe of the dune or any permanent habitable structure (whichever is farther seaward). Public use is prohibited in the buffer zone, but the public's customary use is protected on the remainder of the beach. Walton County Ordinance No. 2016-23 (copy on file with the author). The Commission voted to stay enforcement of the new ordinance until April 1, 2017. Several residents have filed litigation challenging the ordinance. See Second Amended Complaint, Alford v. Walton County, No.: 3:16-cv-00362-MCR-CJK (N.D. Fla. Dec. 20, 2016) (alleging that the ordinance violates Plaintiff's First Amendment rights). 
reinforce the very simplistic-binary thinking that some property rights rhetoric promotes: the "it's my property or it's not" argument. This rhetoric tends to create hostility toward even reasonable and legitimate government regulations. ${ }^{300}$ In this case, regulation would very likely be necessary to protect the public's clearly established rights of access to water and public trust lands, as well as rights acquired through customary use. ${ }^{301}$ Moreover, such an approach would increase the cost and decrease the options for local governments considering retreat as an option for adaptation. ${ }^{302}$

Balanced against these arguments are littoral owners' property rights. These fundamental rights deserve protection, and courts must consider seriously their contours and what protection is warranted. However, as illustrated above, allowing the property line to become move underwater is unlikely, ultimately, to serve landowners' interests. Indeed, such an outcome would likely prove a pyrrhic victory in most cases. ${ }^{303}$ Moreover, there are avenues open to landowners who wish to protect their lands from erosion. ${ }^{304}$ For better or worse, Florida statutory law and current regulatory practice generally permit landowners to construct sea walls to protect their property against erosion. ${ }^{305}$ While that policy may be maladaptive, ${ }^{306}$ it

300. See Doremus, supra note 3, at 1106-08 (discussing the controversy between private coastal owners' right to armor property and the public interest).

301. See United States v. Milner, 583 F.3d 1174, 1174 (9th Cir. 2009) (finding landowners' armoring trespassed and interfered with tribal rights to tidelands).

302. See J. Peter Byrne \& Jessica Grannis, Coastal Retreat Measures, in THE LAW OF Adaptation to Climate Change: U.S. and International Aspects 272 (Michael Gerrard ed., 2011) (surveying relative advantages of retreat and barriers to local governments implementing such a policy).

303. See Ruppert \& Grimm, supra note 192, at 29, 30-32 (noting the eventual likelihood that it will become impossible or impracticable to maintain essential public services in many coastal areas subject to regular inundation).

304. Charles R. O’Neill JR., Structural Methods for Controlling Coastal Erosion 1-3 (1986), https://www.seagrant.umaine.edu/files/chg/nyexth86001.pdf (listing methods of coastal erosion control with corresponding advantages and disadvantages depending on location).

305. The Florida DEP may authorize installations such as seawalls, groins, and jetties upon consideration of facts and circumstances, including potential effects of the structures on the beach-dune system. The DEP may grant permits to protect private structures that are vulnerable to damage from frequent coastal storms. FLA. STAT. § 161.041 (2012). The DEP also issues permits allowing future installations on structures not yet vulnerable to damage, contingent upon the occurrence of specified changes to the coastal system that would render the structure vulnerable. Id. § 161.085(2)(b) (2009). In addition, the DEP grants permits to protect structures on a property surrounded on both sides by properties with sea walls under what is known as the gap-closing provision. Id. § 161.085(2)(c).

306. Ruppert, supra note 31, at 75 (explaining Florida's policy on rigid coastal armoring). Florida's current rules require that sea walls be constructed only to withstand historic storm surges do short-sighted landowners no favors; it seems likely that owners who have constructed sea walls will find these eroded and overtopped in time. Urbina, supra note 148 (illustration shows an overtopped sea wall during a high tide in Isle of Palms, South Carolina). Destroyed sea walls could be seen along Florida's northeast coast in September 2016 after Hurricane Matthew passed near to the coast (photos on file with author). 
does provide landowners an avenue to protect their interests in advance of erosion. Allowing reasonable steps to protect coastal property before erosion seems preferable to a rule that would encourage landowners to reclaim after erosion has occurred.

As a practical matter, reclamation, after erosion has submerged the property, is likely unaffordable and infeasible for most property owners absent governmental sponsorship and funding. ${ }^{307}$ Thus, if courts endorse a rule that fixes the property line notwithstanding sea-level rise, the right to use or to meaningfully control that property would likely be a hollow promise.

Moreover, Florida statutory law provides additional protection for littoral landowners' interests in adjacent submerged lands. ${ }^{308}$ Florida Statute $\S 161.041$ permits littoral landowners to seek permission to undertake activities on sovereign submerged lands for various purposes. ${ }^{309}$ This mechanism would remain available to littoral landowners, even if the boundary migrated. This preserves for landowners the only real value they retain after submersion: a right to use the submerged lands for various purposes connected with their littoral property, including protecting that property. This statutory mechanism provides a practical administrative framework consistent with the constitutional protections for sovereign lands, and incorporates some modest protections for the public interest. ${ }^{310}$

Thus, a court can reconcile the common law of property and the constitutional and common law protections for sovereign submerged lands in a context of ongoing coastal erosion. A court may hold that, generally, the boundary of littoral lands should migrate with the MHWL. This will protect the public's strong interest in retaining submerged lands in sovereign ownership, as well as avoid many practical problems that an alternate outcome would create. Ultimately, this will protect both the

307. The cost of undertaking private beach restoration is one obstacle. Added to this, undertaking restoration on a single parcel will not be effective in many settings. Therefore, private landowners who wish to undertake this initiative without governmental leadership or support also face administrative and collective action obstacles. Where landowners have enormous wealth and a large investment in the property, or where the form of ownership already has a collective dimension, as in a large condominium or neighborhood association, this may prove more feasible.

308. FLA. STAT. § 161.041.

309. See id. (authorizing the Florida Department of Environmental Protection to grant coastal construction permits for construction of structures and physical activity, such as dredging of inlet channels or deposition of beach material on sovereignty lands below the mean high-water line); see also FlA. STAT. § 253.0347 (2017) (authorizing the lease of sovereign submerged lands for private residential docks and piers).

310. These protections include the requirement that the activity not interfere with the public use of any area of a beach seaward of the mean high-water line, or, if such interference is unavoidable, that the landowner provide alternate access. See, e.g., FLA. STAT. §§ 161.041, 161.085 (codifying permitting structures for individuals to protect their private property). 
landowners' and the public's interests. The approach will free landowners from paying taxes on these lands while allowing them to use sovereign submerged lands when feasible, pursuant to the statutory framework.

However, adopting a migratory boundary as the default rule does not need to exclude courts from considering fairness to landowners, albeit on a case-by-case basis. Because of the strong protections accorded to private property, a court must consider factors in individual cases that affect fairness.

For example, the timing of the landowner's investment relative to the pattern of erosion might be relevant to the court's analysis. For a landowner who purchased the land before anyone knew that the area was critically eroding, and for whom loss of the property value would be significant, fairness might dictate allowing the boundary to remain fixed notwithstanding the public interest. However, if a landowner purchased the property or made substantial improvements after the likely impact of erosion and storm surges became evident, equity would be less in their favor. In such a case, the court will likely find that fairness did not require overriding the public interest.

However, the availability of federally subsidized insurance and other support or options (such as offers from local or state governments to purchase rolling easements or other interests in the property) from state, federal, and local governments might similarly offset fairness concerns.

This discussion concludes that public interest would, in most cases, outweigh fairness to individual landowners and, thus, require an ambulatory boundary in the context of sea-level rise. However, a court might balance interests differently and conclude that fairness to landowners outweighs the public interest in keeping sovereign lands. In such cases, the court will hold that fixed boundaries should remain, despite the practical concerns noted above. This would prioritize private property rights over public interest. A justification for this approach would be the strong protection given to private property, and the background rule that boundaries ordinarily remain fixed. ${ }^{311}$

However, invoking the background rule regarding property boundaries is not an automatic trump. As noted above, this rule is already subject to numerous exceptions, sometimes in contexts that are arguably less compelling than this one. ${ }^{312}$ Common law recognizes exceptions allowing

311. See supra note 308 and accompanying text (discussing the protections available to private landowners in property law).

312. See supra note 278 and accompanying text (arguing that the default rule inhibiting change in boundaries absent voluntary conveyance or eminent domain is already subject to numerous exceptions). 
changes to boundaries and rules regarding the validity of titles to achieve values like fairness, ${ }^{313}$ productive use of land, ${ }^{314}$ and efficiency. ${ }^{315}$ In other contexts, property rights created by servitudes lose protection when circumstances change so significantly that the benefits of the covenant no longer accrue. ${ }^{316}$

Moreover, as described above, applying the background rule creates substantial, practical problems. In many cases, activities on the newly submerged lands require not only permits under state law, but also federal permits under the Rivers and Harbors Act. ${ }^{317}$ Where state agencies may be more susceptible to local political pressure to grant permits to appease landowners, the Army Corps of Engineers might be less easily swayed by this pressure. ${ }^{318}$ In addition, the Corps' more rigorous engineering and environmental standards and analysis would likely doom attempts by landowners to reclaim submerged property. ${ }^{319}$

Moreover, the likelihood that more pervasive efforts to reclaim submerged areas will interfere with public access to water for recreation, navigation, and commerce means that landowners will "own" the land only in name, possessing few of the rights typically associated with property ownership. $^{320}$ In this sense, fixing the coastal property boundary in the context of sea-level rise is more of a disservice to littoral landowners. Such a rule misleads purchasers, causing them to overestimate the nature of the rights they will have in the future as seas rise. In addition, encouraging landowners to think of permanently submerged lands as their property will generate conflict between the public and littoral landowners seeking to determine the bounds of their rights.

For all these reasons, even if a court holds the ambulatory boundaries framework inapplicable, the court will likely adopt a default rule favoring

313. For example, the common law protection of bona fide purchasers and its codification in recording statutes reflects a decision to achieve fairness at the expense of bedrock common law principles regarding the validity of title and the priority accorded an earlier transfer. PowELL, supra note 6, § 82.01[3].

314. For example, the doctrine of adverse possession requires actual use of the property for the designated statutory period, thus privileging productive use of land over non-use.

315. One value served by the concept of adverse possession is to ensure efficient allocation of land. See, e.g., PowELL, supra note 6, § 91.01[4] n.30.

316. POWELL, supra note 6 , § 66.02[2].

317. FLA. STAT. § 161.041 (2012); see also 33 U.S.C. § 401 (1970) (prohibiting construction of any physical structure on navigable waters unless the Army Corps of Engineers grants a permit).

318. David L. Hankey, Sections 9 and 10 of the Rivers and Harbors Act of 1899: The Erosion of Administrative Control by Environmental Suits, 1980 DUKE L.J. 170, 182 (1980) (explaining that Congress urged the Corps to follow the statute strictly).

319. Id. at 182-83.

320. See Sax, Sea Level Rising, supra note 5, at 644 (explaining that landowners making reclamation efforts have a duty to provide public access to the water). 
an ambulatory boundary, absent a finding that fairness or the public interest necessitates a fixed boundary. Adopting a default rule is an important step in creating clarity and consistency in the application of the law. At the same time, adopting a default rule, rather than an absolute rule, acknowledges the tension inherent in reconciling these two bodies of law (the ambulatory boundaries framework and the constitutional, statutory, and common laws) and the values they protect. Thus, it leaves room for courts to deviate from the default rule when fairness to the individual landowner or the public interest dictates as much.

This approach-sweeping away the ambulatory boundaries framework-while bold, has the merit of creating clarity long sought by litigants, courts, and commentators. Given the challenges all parties will face in efforts to adapt to sea-level rise, clearing away the debris and clarifying the question of boundaries frees resources to address questions more meaningful than whether an unaided human eye can observe the changes on the coastline as they occurred. However, even if non-application of the framework is justified under basic principles of common law, courts will likely hesitate to make a decision that could be characterized as a change in the law, rather than a mere change in the facts (which affects the determination of what law applies). ${ }^{321}$

\section{Objections to the Proposal to Set Aside the Ambulatory Boundaries Framework in the Context of Sea-level Rise}

The sections above outline two approaches courts might take in recognizing the legal significance of sea-level rise and adapting the law. However, because the second of these-a decision not to apply the erosionavulsion doctrine-represents a decisive change in long-standing precedent, it would inevitably draw scrutiny and face serious challenges. ${ }^{322}$ Moreover, as noted above, courts are rightly reluctant to take steps that could be characterized as changing the common law. ${ }^{323}$ This section addresses some of these concerns. Although common law property doctrines are notoriously sticky and criticized for their adherence to antiquated rules, courts and judges have long recognized that they are not required to adhere to rules when circumstances have changed, particularly when applying the older

321. See Jones, supra note 247 , at 457-58 (explaining that courts prefer to distinguish old rulings rather than overrule prior decisions).

322. See id. at 457-58 (discussing the doctrine of stare decisis and its binding effect on lower court decisions).

323. See generally Stop the Beach Renourishment, Inc. v. Florida Dept. of Envtl. Prot., 560 U.S. 702, 722 (2010) (discussing the potential judicial elimination of common law private property rights). 
doctrines, which no longer serve their purposes. ${ }^{324}$ In Riddle v. Harmon, a California Court of Appeals rejected the rule that a joint tenant of real estate could not transfer property to herself as tenant in common without use of a straw person. ${ }^{325}$ The court highlighted that the rule against allowing a joint tenant to transfer to herself as a tenant in common was premised on the anachronistic practice of livery of seisin as the means of conveyance. ${ }^{326}$ Changes in the means of conveyance made the prohibition on transfer of an interest to oneself anachronistic. ${ }^{327}$ The court also highlighted that the rule aligned with common sense and efficiency, as well as effectuating the intent of the grantor. ${ }^{328}$ The court cited the famous lines from Oliver Wendell Holmes's The Path of the Law:

It is revolting to have no better reason for a rule of law than that so it was laid down in the time of Henry IV. It is still more revolting if the grounds upon which it was laid down have vanished long since, and the rule simply persists from blind imitation of the past. ${ }^{329}$

In Garner v. Gerrish, the New York Court of Appeals rejected the rule that a lease at the will of the lessee must also be at the will of the lessor. ${ }^{330}$ It noted that the rule was generally accepted throughout the United States in the 19th Century, but nevertheless rejected it. ${ }^{331}$ Like the "straw man" in Riddle v. Harmon, the court emphasized the rule's link to the obsolete practice of livery of seisin, and noted that the rule had been criticized for violating terms of the agreement and frustrating the intent of the parties. ${ }^{332}$

Throughout the 20th century, courts rejected or revised a number of common law doctrines in the realm of landlord-tenant law that became obsolete because of the changes in the world around them. The archaic rules fit poorly with the social values recognized as important in property

324. Lovett, supra note 10, at 469.

325. Riddle v. Harmon, 162 Cal. Rptr. 530, 534 (Cal. Ct. App. 1980). Prior to the decision, a joint tenant could achieve the same objective by conveying her interest to a third person (the "straw" person), which severed the joint tenancy, creating a tenancy in common. Id. at 532. The third person could then immediately reconvey the interest in the property, now unburdened by the right of survivorship, to the original joint-tenant conveyor. Id.

326. Id. at 533.

327. Id. at 533-34.

328. Id. at 534 .

329. Id. (quoting Oliver W. Holmes JR., COllected Legal PaPers 187 (1920).

330. Garner v. Gerrish, 473 N.E.2d 223, 225 (N.Y. 1984).

331. Id. at 224.

332. Id. 
law. ${ }^{333}$ For example, courts rejected self-help as a remedy because it induced violent conflict and deprived landlords of adequate judicial remedies. ${ }^{334}$ Similarly, the implied warranty of habitability was first adopted in Javins v. First National Realty Corporation. ${ }^{335}$ Numerous states adopted it later, recognizing changes in the landlord-tenant relationship in 20th century society. ${ }^{336}$ In other words, implicit factual assumptions about the nature of the housing tenants sought, their ability to perform necessary repairs, and the relative bargaining power of landlords and tenants that underlay the doctrine were no longer warranted. ${ }^{337}$

Similarly, in real estate transactions, state courts have steadily rejected the doctrine of caveat emptor, and moved to impose a duty to disclose latent defects on sellers of real property. ${ }^{338}$ State courts criticized the old rule as allowing conduct that violates fair dealing and good faith. A number of the courts revisiting the doctrines recognized that there were relevant doctrinal forces beyond the rule in question. In some cases, this included doctrines, principles, or values drawn from contract or tort law. ${ }^{339}$ Similarly, a court setting aside the ambulatory boundaries framework could acknowledge the importance of constitutional and common law principles, and values associated with protecting the public trust and the sovereign ownership of submerged lands in determining coastal boundaries in an era of sea-level rise. ${ }^{340}$

There is also precedent for courts incorporating recognition of changed circumstances into substantive property doctrine. ${ }^{341}$ For example, changed circumstances are one of the accepted rationales for arguing that a real covenant or equitable servitude should be terminated. ${ }^{342}$ Courts recognize that even though a real covenant or servitude is an interest in land, it cannot survive substantial changes that make the area no longer suitable for the

333. See Berg v. Wiley, 264 N.W.2d 145, 151 (Minn. 1978) (discussing the departure from a common law rule).

334. Id.

335. Javins v. First Nat'l Realty Corp., 428 F.2d 1071, 1082 (D.C. Cir. 1970).

336. See Hilder v. St. Peter, 478 A.2d 202, 207-08 (Vt. 1984) (finding that 20th century tenants are in an inferior bargaining position to their landlords because tenants are not experienced in maintenance work).

337. Id.

338. See Johnson v. Davis, 480 So. 2d 625, 629 (Fla. 1985) (discussing the duty to disclose latent defects to buyers).

339. See id. at 628 (discussing tort law's relation to the duty to disclose latent defects).

340. E.g., State of Florida v. Fla. Nat'l Props., Inc., 338 So. 2d 13, 18 (Fla. 1976) (considering constitutional and common law principles and sovereignty in declaring a new coastal boundary statute unconstitutional).

341. Jeffrey A. Blackie, Note, Conservation Easements and the Doctrine of Changed Conditions, 40 HASTINGS L.J. 1187, 1206-07 (1989).

342. Id. at 1188. 
uses envisioned by the restriction. ${ }^{343}$ Moreover, the scope of easements has been allowed to change and expand to reflect gradual evolution in technology. ${ }^{344}$ All of these rules have developed to allow property law to adapt when changes external to the law affect the law's ability to achieve its goals. ${ }^{345}$ Here, the law governing ambulatory boundaries faces serious challenges, not only because of its inherent limitations, but also because changes external to the law have redefined and broadened the scope of the interests at stake.

Nonetheless, one might distinguish all of these instances by highlighting that the changes resulting from sea-level rise are not mere changes in remedy or recognition of a property owner's new duty. Instead, they are changes that affect the very method by which courts will determine coastal boundaries. ${ }^{346}$

One response to this concern is that coastal boundaries are already ambulatory. ${ }^{347}$ Landowners currently take property subject to a set of rules that are sufficiently arcane and vague that few likely understand the process by which their boundaries are determined. ${ }^{348}$ Moreover, these rules make future boundaries entirely unpredictable, dependent as they are on the vagaries of the ocean. ${ }^{349}$ Thus, the idea that landowners have somehow relied on the existing doctrine and should be protected in that reliance is a weak claim. ${ }^{350}$ Moreover, property law is no stranger to doctrines that can effect equally if not more significant changes to an owner's rights-for example, the doctrines of adverse possession and prescription. ${ }^{351}$

A final concern that eliminating the ambulatory boundaries framework raises is the risk that a court would consider this as changing the common law in a way that would justify a claim of a "judicial taking," or a

343. Id. at 1207-08.

344. See Marcus Cable Assocs. v. Krohn, 90 S.W.3d 697, 701 (Tex. 2002) (recognizing that the use of an easement may change to accommodate technological developments).

345. Blackie, supra note 341, at 1217.

346. WYMAN \& WILLIAMS, supra note 71, at 1959-60.

347. See Maloney \& Ausness, supra note 59, at 195, 197 (explaining that coastal boundaries are defined by the average rise and fall of the tide).

348. E.g., Wyman \& Williams, supra note 71, at 1967-68 (summarizing a case where a court held defendant did not trespass because it was not clear where the boundary was).

349. Id. at 1958, 1967.

350. See Riddle v. Harmon, 162 Cal. Rptr. 530, 533 (Cal. Ct. App. 1980) (quoting Roger J. Traynor, No Magic Words Could Do It Justice, 49 CAL. L. REv. 615, 622-23 (1961)) ("We are given to justifying our tolerance for anachronistic precedents by rationalizing that they have engendered so much reliance as to preclude their liquidation. Sometimes, however, we assume reliance when in fact it has been dissipated by the patent weakness of the precedent. Those who plead reliance do not necessarily practice it.”).

351. POWELL, supra note 6, § 68.02 . 
deprivation of property without due process. ${ }^{352}$ This only seems a risk with the comprehensive approach outlined above.Moreover, courts have yet to adopt a judicial takings theory. However, four of the eight Justices on the Supreme Court at the close of the Obama Administration indicated support for such a theory. ${ }^{353}$ It is impossible to predict what such a doctrine would look like, given that it does not exist. If the Court adopted the approach laid out by the late Justice Scalia, in a portion of the Stop the Beach Renourishment opinion joined by Justices Alito, Roberts, and Thomas, a judicial taking would be found if a court "recharacterize[d] as public property what was previously private property." 354 Justice Kennedy, in an opinion joined by Justice Sotomayor, noted that the common law tradition allows "incremental modifications to property law....”355 His opinion highlighted problems with the judicial takings theory and noted the constraints already imposed by the due process clause, which prevents state courts from eliminating or substantially changing "established property rights, which are a legitimate expectation of the owner,"356 or abandoning settled principles. ${ }^{357}$ Applying these as the test for judicial taking, one can argue that setting aside the ambulatory boundaries framework in the context of sea-level rise does not recharacterize property, change established property rights, or abandon settled principles. ${ }^{358}$

First, as noted above, deciding whether facts have changed in materially relevant ways, such that a body of law is not the applicable rule

352. See J. Peter Byrne, Stop the Stop the Beach Plurality!, 38 Ecol. L. Q. 619, 625 (2011) (discussing the Supreme court's acknowledgement of the possibility that a state court might violate due process by an interpretation of state property doctrine that lacked a "fair and substantial" basis in precedent).

353. Stop the Beach Renourishment v. Fla. Dep't of Envtl. Prot., 560 U.S. 702, 713-15 (2010). For critiques of this theory, see John D. Echeverria, Stop the Beach Renourishment: Why the Judiciary is Different, 35 VT. L. REV. 475, 490 (2010); Byrne, supra note 352, at 636.

354. Stop the Beach Renourishment, 560 U.S. at 713, 715 ("[A] State, by ipse dixit, may not transform private property into public property without compensation.” (quoting Webb’s Fabulous Pharmacies, Inc. v. Beckwith, 449 U.S. 155, 164 (1980))). In a footnote, Justice Scalia amplified the level of clarity about the existence of the claimed right: "A property right is not established if there is doubt about its existence; and when there is doubt we do not make our own assessment but accept the determination of the state court.” Id. at 726 n.9. Justices Breyer and Ginsburg in a concurrence expressed the view that no taking occurred, but also specified that the Court need not and should not reach the issue of whether a judicial takings theory was valid. Id. at 742-45 (Breyer, J., concurring).

355. Id. at 736 (Kennedy, J., concurring).

356. Id. at 737 .

357. Id. at 738.

358. See Michael Allan Wolf, Strategies for Making Sea-Level Rise Adaptation Tools "TakingsProof,” 28 J. LAND USE \& ENVTL. L. 157, 193-94 (2013) (explaining that clarifying unsettled property rights does not eliminate established property rights). 
of decision, does not change the law. It merely determines the proper law to apply, which is a fundamental judicial role. ${ }^{359}$

Second, this article's premise is that the changing nature of the environment-not the courts-has unsettled the law. As John Echeverria noted, the Supreme Court has repeatedly confirmed that the common law can and does change, and that changed circumstances can justify such evolution in the law. ${ }^{360}$ The argument for not applying the ambulatory boundaries framework is precisely that circumstances have changed.

Third, it is important to recall that coastal property boundaries are not settled under existing law. ${ }^{361}$ Those who own land at the water's edge already are and have always been subject to boundaries that change when the ocean moves. ${ }^{362}$ Thus, landowners cannot claim to have a fixed expectation to own property at the water's edge in the future. ${ }^{363} \mathrm{~A}$ court seeking to apply law in new circumstances is clarifying the law, not changing it. ${ }^{364}$ Thus, as Michael Wolf emphasizes, the incoherent and confusing state of the common law in this area works against a judicial takings claim under the plurality opinion's analysis. ${ }^{365}$ Added to that, the presumption that most states favor the accretion-erosion doctrines means that upon inundation, the boundary presumptively moves, and inundated areas become public. ${ }^{366} \mathrm{~A}$ judicial decision stating that this framework no longer applies inevitably does not help or hurt any particular landowner. More importantly, the root cause of any change to the property owner's rights is not the judicial decision, but a documented force of nature that has always been recognized as having the power to trigger legal changes: inundation of property. ${ }^{367}$ Finally, the leading treatise writers suggest that the ambulatory boundaries doctrines may simply be rules of construction, not positive rules of law for the ascertainment of boundaries. ${ }^{368}$ If a court adopts this view, the rules have even less force. A claim of a property right grounded in a rule of construction would seem weaker than one grounded in a rule of law. Thus, even the specter of a judicial takings claim does not preclude a court from seeking to adapt the law in this area.

359. CARTER \& BURKE, supra note 259, at 27, 29, 45.

360. Echeverria, supra note 353, at 636.

361. Christie, supra note 3, at 26-27, 30.

362. Id.

363. Id.

364. Wolf, supra note 358, at 194.

365. Id.

366. Sax, Accretion, supra note 4, at 353.

367. See Wolf, supra note 358, at 191 (analyzing issues as applied to a ban on armoring).

368. TIFFANY, supra note 54, § 1220; PoWELL, supra note 6, § 66.03[1]. 


\section{CONCLUSION}

The common law framework for ambulatory boundaries developed to address changes in the shoreline that were perceived as unpredictable, bidirectional, and episodic, with limited geographic extent. This paper argues that cases of coastal erosion in an era of predictable, ongoing, unidirectional, and pervasive sea-level rise are materially different from those that justified applying the ambulatory boundaries framework. It further claims that the rationales supporting application of these doctrines from their earliest common law expression to today do not support their application in this new setting.

Courts may respond by applying the ambulatory boundaries framework with explicit consideration of how sea-level rise necessitates changes in the doctrines in order to align the law with the rationales that support the framework. Alternatively, courts may conclude that the framework is inapplicable in this new setting, and then apply the substantial remaining body of law that governs property boundaries and ownership, and control of public trust and sovereign submerged lands-without the overlay of the erosion-avulsion framework. This body of law, composed of constitutional, statutory, and common law doctrines, will provide ample guidance for courts in the absence of the ambulatory boundaries framework. This article suggests that courts should consider these options in order to better align the law with the reality of a coastline increasingly shaped by sea-level rise. 